\title{
Students' Empathy for the Environment through Eco-Art Place-Based Education: A Review
}

\author{
Asvina Sunassee ${ }^{1, *}$, Chandradeo Bokhoree ${ }^{1}$ and Andrew Patrizio ${ }^{2}$ \\ 1 School of Sustainable Development and Tourism, University of Technology, La Tour Koenig, Mauritius; \\ sbokhoree@umail.utm.ac.mu \\ 2 Department History of Art, University of Edinburgh, Edinburgh EH 99, UK; a.patrizio@ed.ac.uk \\ * Correspondence: sunasseea@live.com
}

Citation: Sunassee, A.; Bokhoree, C.; Patrizio, A. Students' Empathy for the Environment through Eco-Art Place-Based Education: A Review. Ecologies 2021, 2, 214-247. https:// doi.org/10.3390/ecologies2020013

Academic Editor: Valery E. Forbes

Received: 3 December 2020

Accepted: 9 May 2021

Published: 20 May 2021

Publisher's Note: MDPI stays neutral with regard to jurisdictional claims in published maps and institutional affiliations.

Copyright: (c) 2021 by the authors. Licensee MDPI, Basel, Switzerland. This article is an open access article distributed under the terms and conditions of the Creative Commons Attribution (CC BY) license (https:// creativecommons.org/licenses/by/ $4.0 /)$.

\begin{abstract}
The existing state of the world climate creates the need for an educational programme that incorporates effective proposals for the environment that can be practically implemented. The present environmental education literature has changed due to new study paradigms. Understanding how students relate to nature, how their personal beliefs and behaviours are influenced, and how their actions are affected can provide an increased understanding of how they can contribute meaningfully to global objectives. This paper aims to analyse educational research papers published in the area of environmental art education in order to find the factor with the greatest effect and illuminate how they can help to improve the measures implemented. This study paper (i) focuses on students' engagement with an environment curriculum; (ii) demonstrates the need for action related to the environment; (iii) encourages critical thinking; and (iv) demonstrates students' independent thinking and rational decision making. The findings show that such research can help to improve environmental art education based on action and take future research challenges into account.
\end{abstract}

Keywords: eco-art education; empathy; place-based education; environment; art education; proenvironment behaviour; nature study

\section{Introduction}

Individuals are reliant on Earth's habitats for their entire lifetimes and now face some of the world's most challenging ecological problems (National Academy of Sciences, 2020, World Watch Institute, 2016) [1,2]. Within the context of the ecological crisis, our capacity for growth is disappearing. Orr (1992) stated that "The requirements of water, food, animation or holy inspiration cannot meet our climate" (pp. 263-264) [3]. While there is scientific evidence available to explain the ecological crisis, the behaviour responsible for the severe problems that we face has not fundamentally changed. Despite the increased coverage of environmental concerns in news, magazines, and television, the problems remain unresolved, even though the public and private sectors receive information from us on ecological issues. Many environmental challenges that face society, however, must be discussed and resolved. This can only happen if large-scale community support is given (Miller, 2004) [4]. Environmental education, as advocated by Moser (2007), is needed to ensure that more help is given to initiate collective action and behavioural change in relation to environmental problems [5].

Environmental education aims, based on multidisciplinary expertise, to transform human behaviour into nature-friendly actions and promote environmentally aware decisionmaking. Its aim is to bring about improvements in social behaviour to achieve environmental regeneration, restoration, and conservation [6]. Environmental education also helps to remedy these circumstances and can play an important role in addressing the major ecological challenges facing the world. Furthermore, art is also viewed through the extension and communication of scientific knowledge, the education of people, and prevailing 
paradigms. In order to draw attention to significant environmental problems, artists produce art. Art is now seen as a significant means of connecting people with environmental concerns. Art education is one way to achieve this (Johnson and Manoli, 2007) [7]. Environmental education can also strengthen the influence of ecological learning through art education. For example, ecological literacy should be included in the school syllabus (Orr, 1994) [8]. Researchers have endorsed the argument for environmental education in this regard. The key criterion for including it as a subject is that this education not only improves children's attitudes but could also help society deal with environmental issues (Orr, 1994). The promotion of various approches to educate students about the environment will help to win over their hearts and minds (Graham, 2007) [9].

New studies on topics such as environmental art education and eco-art education will help to promote this approach. Environmental art education is not an independent field, but an aggregation of numerous studies such as art, science, and education in relation to the environment (Orr, 1994). Eco-art education is another name for this. It includes elements such as art education and outdoor and environmental education (Orr, 1994). Ecoart training aims to increase awareness and concern regarding environmental principles such as sustainability (Hansen, 2009) [10]. This new area of study, environmental art education, is currently gaining prominence, because arts play an important role in the sustainability of social activities in school and university programmes (Hansen, 2009). Inspired by eco-art education, this latest trend has been inspired by the environmentrelated ideas and concerns of activists, e.g., Basia Irland, Joseph Beuys, and Mel Chin (Greenmuseum, 2010) [11]. These activists encourage the public or community through their eco-artwork and by offering new solutions to environmental problems. In the era of environmental concerns, the arts have aimed at tackling environmental issues that, as Wallen (2014) says, are worth exploring in order to find ways to solve the problems that the world has to face [12]. Wallen argues that art can be a significant contributor to the creation of a sustainable society. By its capacity to express thoughts and emotions, eco-art will awaken the consciousness of all human beings. It is also prescribed for students to improve their cognitive skills, representing one of the best platforms to achieve this. Moreover, cultivating environmental empathy encourages a sense of connection.

This sense can be described as a type of compassion, an understanding of nature (Cheng and Monroe, 2012) [13]. Eco-art education allows students to create this knowledge of the environment and helps students to construct an ecological model. Wallen states that the connection between empathy and visual experience builds the link between eco-art education and empathy in environmental art. In addition, the interconnected relationship between viewer and object in art can provide various ecological perspectives that improve the empathy between the viewer and the object of the art. Students' sense of relation to the world can be altered in this area by experiential involvement. Researchers have established an ecologically sensitive art curriculum focused on the opportunity to learn about eco-art and respond to environmental concerns (Anderson and Guyas, 2012) [14]. Current educational circumstances have increased their levels of study to allow students to reflect on and examine important issues in contemporary society and safeguard the importance of eco-art education in schools. Eco-art concerns are complex and can encompass such areas as social systems, the environment, public spaces, common capital objects, and local ties. Currently, many scholars and academics in the field of environmental art are working hard to solve these issues (Inwood 2008) [15]. Art teachers are exploring more innovative ways to develop and implement lessons that discuss complex environmental concerns (Hungerford, 2010) [16]. An innovative way to solve such environmental issues via eco-art education is place-based pedagogy. The ecological framework, with a connection between all elements, is built on an educational system centred on places. This stress the principle of "listening to the land" and living in harmony without damaging the Earth (Graham, 2007).

Place-based education is structured to make students and teachers change-makers. We need more successful approaches to environmental issues; therefore, art education needs to be paired with environmental education in order to find the best solutions to 
environmental issues (Graham, 2007). Teachers need to explore the connection between students and nature, climate, and teaching practices that promote environmental concerns (Wallen, 2014). Recently, the Secretary-General of the UN, António Guterres, argued that "rescuing from the COVID-19 crisis represents an opportunity to cope with a global climate emergency and create a sustainable future for all" [17]. He feels that now is the time for leaders to "think bigger and generous". He warns that "there is no one who is able to self-isolate from the world to deal with devastating climate disorder", and that human health is dependent on planetary health.

The purpose of this paper is to investigate the new field of eco-art education and elucidate how eco-art education encourages our youngsters to care for the environment. Research papers have been reviewed and synthesised, within a broad variety of pedagogic frames and with reference to the guidelines made at some stage by experts in this area, to the key characteristics and results of research on efficiency and education techniques. It is hoped that analysing the results of numerous researchers can help us to plan and create new studies, that researchers and educators will focus on their practises and discover current patterns and challenging circumstances for eco-art education, and that new awareness will be raised about future activities. This reveals the significance of art education, empathy, and pro-environmental behaviour in eco-art place-based education. This paper will use art to educate ecological literacy with the aim of motivating lifelong pro-environmental behaviours and enhance students' empathy for nature.

\section{Eco-Art}

Art describes how nature is valued and viewed by humans. Environmental art evolved from the emerging environmental movement. Wallen (2012) stated that earlier forms of environmental art related more to the conception of art than to ecological principles (Wallen, 2012). Inwood (2013) stated that environmental art is a means to create a respectful relationship between the Earth and the viewer (Inwood, 2013). Eco-art is used by activists to draw attention to significant environmental, political, and public issues. Eco-art education is a very recent development. It is an evolving educational approach that uses art to educate students about ecology, with the aim of promoting a deep understanding and caring attitude in learners which will lead to them changing their long-term environmental behaviours (Inwood, 2013). A researcher of eco-art education described their enthusiasm, stating that eco-art offers a creative technique to promote the principles of environmental education and ecological literacy (Inwood, 2013). It also enhances traditional environmental education using the sensory and creative techniques of art education. Inwood states that the literature in this area is inadequate, with referenced publications offering a poor focus on the practices and issues of eco-art education, particularly in elementary education. There will be less curriculum development in the field. Inwood and Leichnitz provide implications for making art classrooms greener, such as conserving energy by switching off lights, using eco-friendly cleaning products, utilising non-toxic processes and materials, and minimising the use of human-made materials. Artists should select art materials which do not cause harm and that will not have a negative impact in the future (Weintraub, 2012). Educating students on why and how to understand the life cycle of products and resources is also important and a significant aspect of helping students integrate sustainability into their production of art. In order to develop art with a low environmental impact, the author suggests the use of objects present in nature and motivates the usage of non-traditional materials and the upcycling of objects such as cardboard, plastics, and CDs (Inwood, 2003). To encourage environmentally friendly practices, teachers will offer assistance to students in developing their choices while creating art. This allows students to create through practice and observation. Researchers state that these choices will have an impact on the environment in the future. Making practices greener is the initial step, but the most significant aspect of eco-art education is evaluating the best way to educate students about it (Weintraub, 2012). 
As we know, our planet is in danger. Every day, we can hear about new environmental disasters, such as bushfires in Australia. Our heart cries when we see animals burning in the news. Can these disasters be stopped? Apathy leads to such destruction. We like to pretend that there are no environmental issues or that the problem is natural in the environment. The keywords in this issue are powerlessness, fear, and the sense of disempowerment. It is necessary to provide students with environment education from a young age to encourage them to become protectors of the environment, but due to the poor quality of existing research on eco-art education, researchers and teachers have little help in creating eco-art programmes. They want to be ecologically aware to foster eco-literacy in their students. This paper aims to review different research papers where researchers have examined the advantages of eco-art education. This will also help us to explain why eco-art education is significant and how we can implement it for students. This will enable us to create knowledge and effective connections which are essential for individual learners, helping them become involved in sustainable actions in their homes, communities, and schools. This paper encourages teachers to incorporate art into content learning and content learning into art, so as to create lessons which will help inspire students by ecological and artistic learning. This paper shows us how eco-art education is the best way to manage the curiosity, desire, and enthusiasm of children relating to the environment. In other words, eco-art education encourages students to love and take measures to protect the environment.

\section{Materials and Methods}

Papers were selected from reputed journals, such as the Journal of Environmental Education, Journal of Human Ecology, Journal of Natural and Applied Sciences, Journal of Aesthetic Education, Journal of Experiential Education, American Journal of Art Therapy, International Journal of Education and the Arts, and Journal of Adventure Education and Outdoor Learning. The main stages of the review process are shown in Table 1.

Table 1. Main phases of the review process.

\begin{tabular}{lll}
\hline \multicolumn{1}{c}{ Stages } \\
\hline 1 & Planning and objective & Identification of the research objective \\
\hline \multirow{3}{*}{$\begin{array}{l}\text { Data collection } \\
\text { Analysis and interpretation }\end{array}$} & $\begin{array}{l}\text { Searching review of papers } \\
\text { Classification of the papers } \\
\text { Obtaining preliminary findings }\end{array}$ \\
\hline \multirow{2}{*}{ Presentation } & $\begin{array}{l}\text { Key words } \\
\text { Study of the research papers } \\
\text { Creating descriptions }\end{array}$ \\
\hline
\end{tabular}

A personal analysis was used to select and interpret the research documents. The first step in the selection process was to read the abstracts of the research papers published in these journals; only papers that fulfilled the criteria of this paper were taken into consideration. Research papers were selected that fulfilled the following requirements: (i) research papers exploring the role of students in eco-art education; (ii) research papers discussing direct student engagement in an environmental programme; and (iii) research papers dealing with students' attitudes, behaviour, feelings, or decision-making skills. That being said, because of its suitability in the educational sense, all research on environmental issues was also included. Therefore, based on the selected papers, the quality of the works was verified. A total of 178 journals were taken into consideration. The first round consisted of an open review, which took note of key terms such as art education, education relating to the environment, and education in the fields of eco-art and empathy. The second round consisted of dividing all the research papers into either "empirical" or "non-empirical" 
categories. Empirical research papers were further analysed according to their quantitative or qualitative methodical research techniques, including "case study", and "other" methodologies. Finally, the chosen research papers were read, and after reviewing all the articles selected, the subjects of education were found to be art education, environmental education, place-based education, empathy, natural sciences, environmental behaviour, and ecological art.

\section{Results and Discussion}

There were multiple groups for the outcomes of this research. These topics were compiled from the study papers.

\subsection{Environment Education}

The human population has increased, and its requirements have deteriorated in environmental conditions in terms of technological modification and digitalisation. Some effects of the modern environmental crisis include deforestation, soil degradation, climate change, industry, global warming, mineral resource depletion, and the extinction of certain organisms. This suggests that people lack environmental care. However, the environmental crisis has been declared as a threat to humanity in future. Individuals must take steps to mitigate environmental damage. The public must be made aware of and informed about the environment, its concerns, and the way it must be preserved. When people are given proper information about the environment, they will be more concerned about the dangers to it. This will contribute to a shift in people's behaviour. Larijani proved that education is the best way to address environmental problems (Larijani, 2010) [18]. In their research, the author discussed the need for schools which can achieve better environmental awareness through environmental education (Larijani, 2010). Many researchers have discussed their environmental education concepts. Environmental education is an appropriate way to raise awareness of environmental concerns and promote environmentally friendly values, with the purpose of inspiring young people to act individually and in collaboration with others to address environmental needs. This is the basis of the research of Hungerford, Peyton, and Wilke (1980), and the United Nations Educational and Science Organization [19]. Peyton (1980) pointed out that environment education is a medium for sustainable growth. Chawla (2009) stated that environmental education can promote environmental values and enhance people's willingness to change their behaviour [20]. Chawla further explained that the novel process of environmental education can connect activism with nature (Chawla, 2009). In the Journal of Environmental Education, William (1969), regarded as the first person to discuss environmental education, claimed that it was intended to make the world aware of its biophysical problems and resolve them with a view to the future [21].

\subsubsection{The Origins of Environmental Education}

The roots of environmental education date back to about the 18th century, when the importance of caring for nature was declared by Jacques Rousseau. The naturalist Louis Agassiz, many decades later, reiterated Rousseau's idea and asked his students to observe nature alone, not just through books. In the late 19th century, to promote environmental education, these two influential and important scholars initiated "nature study". In this area, Disinger (1985) has three backgrounds: natural studies, art education, and external education. In the early 19th century, a nature study was implemented to inform students and inspire them to gain an understanding of the environment and care for nature using environmental content [22]. In order to build a relationship with the world, students were taught to observe nature (1985). The nature research of Disinger (1985) is one of the more important environmental education backgrounds in which ecological crises can be overcome. Environmental education also includes art education, which takes into account natural research and explores imagination and emotions. Art education played an important role in addressing social, economic, and environmental problems at the time. The importance of preserving nature and expanding the ideas of peace and happiness 
(Lorbiecke 1996) is stressed by art education [23]. Outdoor education was then developed across important aspects of art education and environmental education (Disinger 1985). Hammerman (1980) cited outdoor education as a motivation to spend significant amounts of time outdoors, merging two forms of education: environmental education and art education [24]. Earlier, environment education in the community was not included in school curricula. In several subjects, for example, different characteristics of the world have been explored in various topics: geography, architecture, design and technology, languages, biology, and social studies (Disinger 1985), as shown in Figure 1. Disinger claimed that environmental education is a novel and influential viewpoint in the education system rather than a creative area. In relation to this, Aydemir (2007) also stressed that a school curriculum that can increase students' understanding of nature, and related issues should be included in an environmentally friendly report. This recent addition is also a major improvement in the structure of education [25].

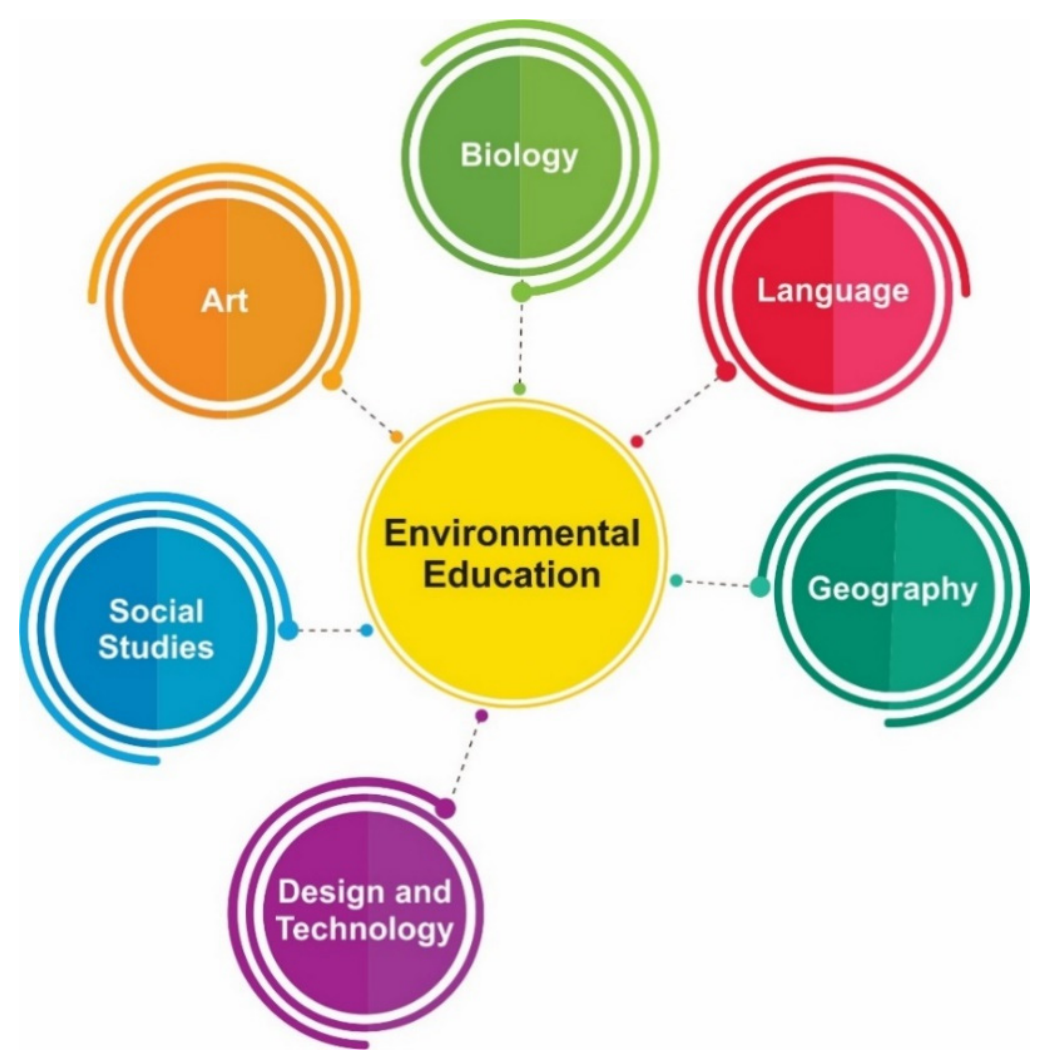

Figure 1. Environmental education comprises aspects of different subjects (Disinger 1985).

4.1.2. The Aims and Objectives of Environmental Education

Hungerford and Volk (1990) stated that environmental education's goals and objectives needed to be clarified [26]. The Tbilisi Conference listed five environmental education objectives:

(1). Awareness: help students gain knowledge about environmental concerns and their issues and to enhance their readiness to consider and act on environmental problems;

(2). Knowledge: enable students to gain an understanding of the workings of the world, how people interact with the environment, how environmental concerns emerge, and how they can be resolved;

(3). Values and attitudes: allow students to experience the value of environmental assessment and encourage students to engage in programmes on environmental conservation;

(4). Skills: train students to develop their skills to investigate environmental issues and to solve them; 
(5). Participation: enable students to engage in environmental conservation programmes by means of constructive acts. The aim is to help students look at the problem and find a solution from their own viewpoint (Hungerford and Volk, 1990: 8-9; Vreken and Rens, 1997:14) [27].

Based on these goals, the idea of environmental education is to help students focus on environmental issues. These goals also demonstrate that environmental education can enable students to think critically about environmental issues and solutions (Hungerford and Volk, 1990). However, in order to achieve these objectives effectively, it is necessary to recognise the role of environmental education in environmental protection (Mistral, 1994:36) [28].

\subsubsection{The Importance of Environmental Education in Environmental Protection}

Environmental education primarily aims to provide students with information to study their environment. It is also an environmental conservation tool, and several experts have demonstrated that there are many advantages to incorporating environmental education in the curriculum.

SACOL stated that, due to environmental education, the process described above is successful:

1. Increase focus on environmental issues and emphasis on operations;

2. This leads to improving environmental knowledge and attitudes;

3. This promotes the need to protect the environment by means of a teaching system focused on activities;

4. This allows students to understand their biophysical climate;

5. This aligns young people's attitudes with current views (SACOL; 1999:18);

6. Environmental education teaches students to avoid environmental practises such as deforestation, pollution, and damage to other living species [29].

Environmental education is an important means to help students better understand the changing conditions of the world (Wilke, 1997) [30]. Students will make decisions and take measures based on their environmental education. This demonstrates how education can sharpen a student's mind and develop their ability to successfully take action through learning. Furthermore, this area of education improves the interaction between the environment and human beings, thus improving their lived experience. This effect can also be called empowerment. Education that gives students the opportunity to solve problems will transform society in terms of environmental protection. Nevertheless, in the context of environmental education, students must acknowledge their position as environmental guardians (Le Roux; 2001: 60) [31]. Hellden (1995) says that before teachers offer information about the environment, they should understand the mindsets and ideas of their students [32]. The goal of this initiative is to effectively provide the skills and experience which students will use for their own benefit and that of the community. Teachers must begin this process by recognising the various mindsets of pupils and adapting their lessons accordingly. This is an effective technique for incorporating environmental education in students' curriculum. Researchers have stated that environmental standards and quality can be preserved through this process. In Boyes and Stanisstreet (1998), the researchers argued that environmental initiatives in schools and educational institutions are necessary in order to effectively implement the practice of environmental education. Research has clearly shown that students have vast capacity to improve their level of skills and know-how by being educated about environmental problems and issues [33]. This makes students trustworthy protectors of the environment. Guo and Zhang (2020) conducted a large survey data with ground-level monitoring station data on air quality. They found that male, younger, and better educated people tended to have higher willingness to pay (WTP). They also noticed that people with a greater understanding of sustainability and more environmentally friendly attitudes are ready to pay more. Environmental education can be seen as vital in order to encourage young people to care about their surroundings [34]. 


\subsubsection{Environmental Education through Teaching Environmental Concerns and Issues}

Environmental education information systems should be expanded as students become older. Systems should also preserve their quality standards in an optimal manner. According to this argument, it is important to look at established information and whether it is consistent with the current environment and what changes are needed in order to develop the system in a rational way. According to Gambro and Switzky (1996), students should be informed about the environment and should be made aware of environmental issues [35]. A study conducted by Kansu and Tüysüz (2009) centred on the relevance of environmental education to students through environmental education [36]. The study looked at the substances of batteries and how they relate to environmental degradation and environmental recycling. This was a seminar in which 256 students took part. Some experiments were carried out before and after the study to assess the importance of teaching students about environmental issues. It was found that there were variations between the pre-test as well as post-test results, and that the post-test results were higher than the pre-test results. Researchers proposed that environmental education should be taught at school for students to develop their awareness of environmental issues and encourage them to serve as protectors of the environment. It was mentioned that it is necessary to promote environmental awareness and also to increase our understanding of nature in order to solve environmental problems (Köse et al., 2011) [37]. A study was conducted to examine the environmental attitudes of 376 students called "Climate, Humanity and Society". A total of 203 female students and 173 male students were enrolled from the college. Both sexes were found to have optimistic views about the world. It was agreed that environmental education is a strong means to raise awareness of nature, as well as its problems. In addition, it has been established that this approach could also reduce environmental issues. The perspective is that schools are not the only place where environmental education can be offered to students. Dunlap (2008) claims that out-of-school education has the same value as in-school education in environmental studies, because both improve awareness in various ways [38]. Another view is that environmental studies should proceed from the primary school level to university education, because a continuation of education on this topic will lead to people being more environmentally conscious. Kasapoğlu and Turan (2008, p. 229) suggested that it is necessary to incorporate environmental studies into school curricula in order to increase the involvement of students in environmental activities [39]. On this topic, Köse et al. (2011, p. 94) also referred to the need for environmental studies for children, suggesting that "Schools and educational institutions should incorporate environmental and environmental studies in their programmes of study: change in climate to raise understanding and inspire children to save nature" (Orr., cited by Stone \& Barlow, 2005, p. 1) [40]. He also claimed in his teaching strategies that issues caused by climate change, including global warming and tsunamis, are difficult and alarming for students to fully understand, because they often have no actual knowledge about or real-life relationship to these events. He went on to suggest that educators should clarify how the effects of climate change impact human beings and the Earth by reflecting on some environmental disaster-related events. These events must be dealt with through a holistic approach that acknowledges the need for students to have a healthy relationship with nature if they are to be protectors of the world (Orr, 1994, 2004; Sobel, 1996) [41]. However, students must be told that they are also a part of the "the natural world" (p. 12). Researchers believe that environmental education is critical in addressing environmental issues [42]. Thomas et al. (2018) also stated the need to educate students about environmental issues [43].

\subsubsection{The Teaching and Learning Approaches Used for Environmental Education}

Environmental education cannot be accomplished in the short term and is a lengthy task. According to Clayton and Myers (2009, pg. 181-182), the attitudes and actions of the student can be influenced by environmental education [44]. They proposed various types of approaches that could be used in environmental education, such as camping, nature walks, and field trips (Volk and MacBeth 1998, listed in Clayton and Myers 2009) [45]. 
There are a variety of human-made nature parks, such as zoos, parks, nature centres, outdoor learning camps, and environmental education centres in the informal economy. In addition, environmental learning can be achieved through information given through television, newspapers, radio, arts, flyers, social media, magazines, video, books, and new technologies. The most important aspect of environmental education is that people should learn by observing nature, because this cannot be simulated through in-room experiments (Clayton and Myers, 2009, 182). The activities that can aid in the learning process are sketches, paintings, the design of environmental projects, and the creation of a garden of plants and flowers (Clayton and Myers 2009). Stevenson (2008) also acknowledges that learners often learn best when they have direct interactions with nature. It can be established that previous experience or knowledge can be a successful method for environmental education, and also that previous knowledge can be obtained from learning institutions. It is therefore necessary to establish lessons in environmental education with a comprehensive understanding of the necessary learning structure (Stevenson 2008) [46].

\subsubsection{Advantages and the Student Performance of the Incorporation of} Environmental Education

Environmental education is a vital aspect of our development, because learners will need to consider the difficulties, they face in addressing environmental issues. There are also several advantages for students who receive environmental education. Ardoin, 2018, stated that with the incorporation of environmental education, the student gains various advantages, including greater interest and commitment, improved motivation, stronger academic performance, and improved social and emotional skills (Ardoin, 2018) [47], as shown in Figure 2. For example, several studies have shown that environmental education encourages students to learn more about the relationship between the environment, oneself, and other topics, such as science, art, and social studies, when environmental education is incorporated into their everyday learning (Chiarotto, 2011) [48]. Students may relate their education to previous knowledge and link it to their thoughts and emotions, thus becoming more environmentally conscious. They will appreciate the value of environmental impacts and establish a closer relationship with nature. Patterson (2010) explored how the incorporation of environmental education in a school can have an effect on students. The results showed increased reliable test scores and that the students had a profound awareness of the environmental problems in society and felt more inspired to make a difference in the world (Patterson, 2010) [49]. Volk and Cheak (2003) conducted research to assess the advantages of an environmental education programme for students aged 11 to 12 years. They concluded that the participants displayed higher levels of environmental awareness, self-esteem, autonomy, and critical reasoning (Volk and Cheak, 2003) [50]. Janet Dyment and Alan Reid (2005) indicated that outdoor education and environmental education should be linked more closely. They stated that students who spend some time outside or in the community during their studies on environmental education receive several benefits. These students will have improved skills in terms of imagination, focus, and confidence, because of improving their abilities by spending time interacting with the natural world [51]. Larson et al. (2010) conducted a week-long study to assess the use of one-week environmental education programmes on children's environmental guidance in a botanical garden between 10 and 12 years of age. Participants and nonparticipants were tested. The pre-test scores for both sets of children were identical, but the results of participating and non-participating children the post-test scores were different. The participants were reported to have scored more than the non-participants (Larson et al., 2010) [52]. According to this report, outdoor programmes can promote positive environmental attitudes among students (Larson, 2010). This study demonstrates the benefits of environmental education as an opportunity for children to enjoy environmental learning through outdoor learning (Larson et al., 2010). There are also some examples of studies involving environmental education initiatives which have positive effects on students. 


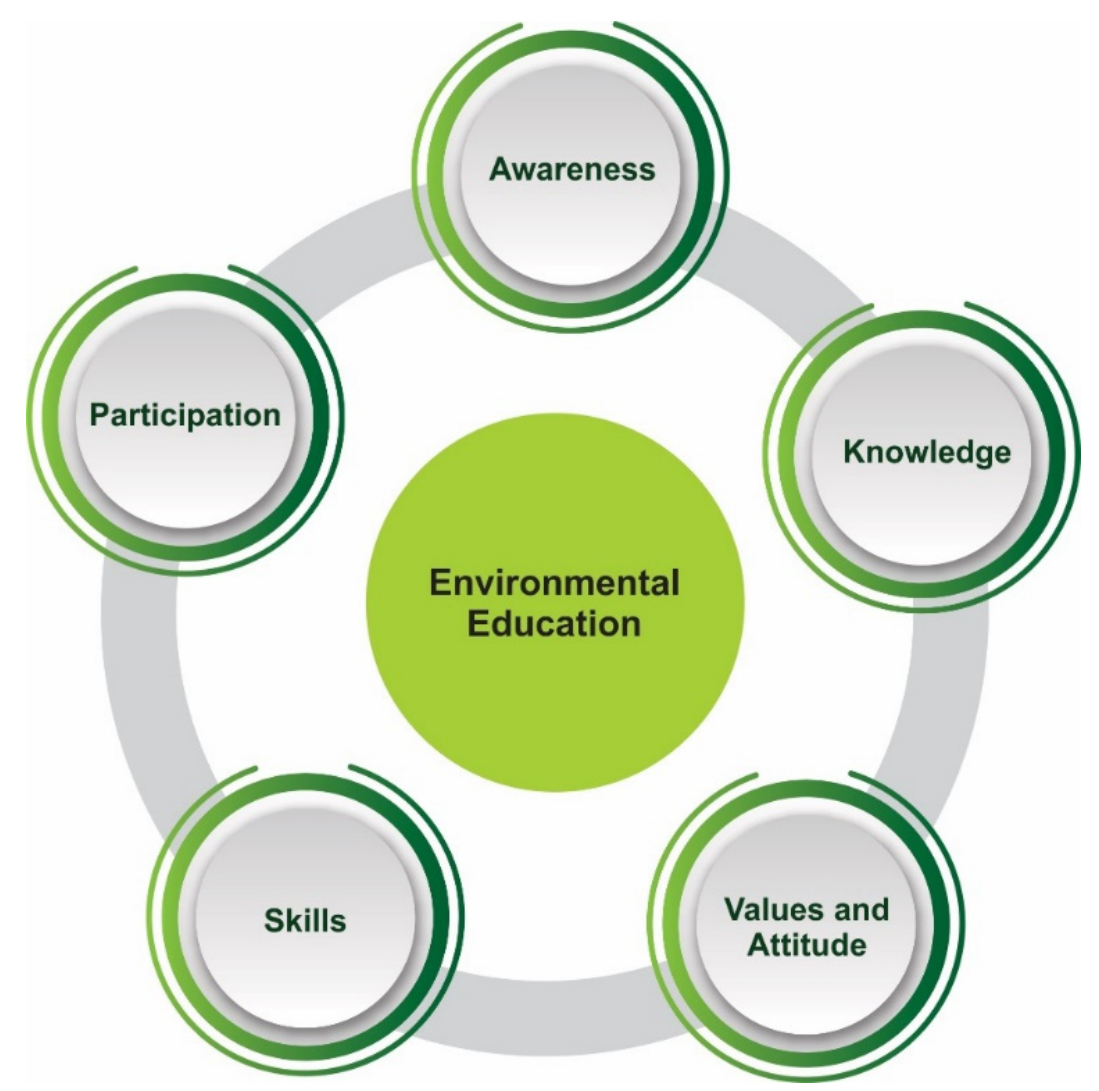

Figure 2. Objectives of environmental education (Hungerford and Volk, 1990).

\subsection{Art Education}

The principal subject of the programme was art education. Arts education is said to offer many advantages, such as improving fundamental and innovative thought, enhancing academic success in non-art subjects such as reading and writing, and improving communication. Art education enables students to relate their individual knowledge and subjective world experience to a structure that is aesthetically pleasing. Fiske E. (1999) stated that "The art students have become more and more part of a broad-based, coherent network, which they have thought they were interested in" (p. 711) [53]. Knight, 2010, said that art is an irreplaceable part of play, taking an active role in people's growth, being adaptable to change, acting as a facilitator for thinking and engaging with people and ideas, and encouraging people to seek answers when issues arise (Knight, 2010) [54]. By introducing art into the curriculum, students are encouraged in a range of circumstances and topics to cultivate their creative thinking. Instead of only thinking about facts (Krug and CohenEvron, 2000), art encourages students to think about ideas in a philosophical or abstract way [55]. Teachers today are able to illustrate ideas through more realistic content and visually simplify complex topics (Krug and CohenEvron, 2000). Art allows students to communicate with and articulate their own values and ideas (Blandy and Hoffman, 1993) [56]. Students' focus, problem-solving abilities, trust, inspiration, abstract thinking, and overall social and emotional growth are also increased by art education (Ontario Arts Council, 1997; People for Education, 2012; Taieb et al., 2010) [57-59]. Art education has been shown to improve school results, particularly in the fields of science, environment, and social studies, when incorporated into the curriculum. The following are the goals of art education:

- Help students across a range of artistic practises to explore, describe, and communicate their thoughts, feelings, and experiences;

- Allow students to develop their talents, techniques, and skills required to create and participate happily in various artistic structures; 
- Encourage students to use creative thinking to view and solve problems;

- Construct an aesthetic experience;

- Strengthen the child's environmental awareness.

\subsubsection{The Visual Arts}

Art is a way to create pictures or images and communicate meaning. Visual arts are an enticing means to broaden and enrich the students' experience of the world. Visual arts allow students to link their life and the world; communicate visually and effectively; and organise their thoughts, feelings, and experiences. Students incorporate expertise with drawing and painting, responding to ideas and trying to understand concepts. In 2015, Fisk et al. reported that education in visual arts promotes aesthetic experience and imagination through the discovery, inquiry, innovation, design, and development of various environments [60]. This improves the feelings and views of students and allows them to be more sensitive to the environment. Visual arts teaching allows students to appreciate visual media and artworks and also encourages them to learn about the curriculum (People for Education, 2013). The visual arts help to build students' understanding of and empathy for their community. The visual arts are a means for students to discover, respond, and understand the world visually, by painting, shading, drawing, etc. Furthermore, drawing is a normal means of contact, feeling, and imagination for students. In various settings, visual arts exercises focus on lines, texture, form, shape, colour, and sound; they cultivate a standard of drawing that students can use intentionally [61]. These characteristics are aspects of visual world elements. Art can express abstract concepts in a simple but powerful way. In addition, Branagan (2005) claims that art produces an environment in which behavioural resistance is disrupted [62]. Endorsing art in digital communication will help environmental learning reach a wider range of audiences.

\subsubsection{Teaching and Learning Programmes for Art Education and the Environmental Education}

Many artists dedicate their lives and their art to the study and solution of environmental issues and become art educators. Banerjee is an environmentally conscious person and makes use of art to attempt to solve environmental issues. Banerjee's work helps to preserve ecological and cultural conditions in the Arctic and fuel the contention that people have no world-related relation (Banerjee, 2007) [63]. He was a major supporter of the nature studies movement of the educational philosopher John Dewey. He suggests that natural sciences should be incorporated into art education. They can also help people "gain empathic insight into the position of plants and animals in life, and build an emotional and anaesthetic interest" (Dewey, quoted in Minteer, 2006, p. 35) [64], as well as enhancing students' understanding of science, botany, and agriculture. Encouraging students to pay close attention to and scientifically study plants, trees, and livestock, as well as to directly engage with their natural surroundings, is intended to establish a thorough understanding of the natural environment. Mantere provides several reasons to affirm that art education will play an important role in the education on the environment [65]. They stressed that knowledge of one's own perception, emotional expression, and subjective processing of events is fundamental to art education. At the same time, art helps students to explore new forms of environmental conservation. Timo Jokela, a Professor of Education, says that visual arts can provide the elements of environmental education which are missing in other fields of education. In Mantere's article, entitled "From Environmental Arts to Environmental Education", they state that arts education changes our schedules and tasks. Accordingly, art constantly produces new ways of observing the world [66].

Jokela describes a significant teaching challenge in terms of environmental education and arts education. The location of the output is determined, because the environment has been established. The researcher then names three kinds of exercises which show how art can lead to education about the environment. Three exercises suggested by Jokela are:

- Seminars to improve environmental attitudes;

- Activities based on and viewing student findings in a responsible manner; 
- $\quad$ Tests to measure the environmental and human measurements and to make major environmental adjustments (pp. 25-36).

\subsection{Eco-Art Education}

In recent years, merging environmental education and visual art education in order to generate environmental awareness has become more commonplace (Inwood, 2013). Eco-art education can also be characterised by using natural or sustainable materials and can also be performed outdoors to let people experience the environment (Inwood, 2013), as shown in Figure 3. Eco-art education is not just a type of education but an entire area of art, with many professional visual artists, including students, practising it. Such artists and learners use their artwork to educate the public and develop innovative solutions to environmental problems (Inwood, 2008). Eco-art education is a means of educating children about global environmental problems. Eco-art education provides people the chance to combine art education and environmental education to make environmental education more available to students (Inwood, 2008). Eco-art education can be described as heart-, soul-, and spirit-related education (Gablik, 1991) [67]. It is focused on arts education, which incorporates environmental education and explores environmental concepts, including the advancement of sustainable development (Inwood, 2008). Tim Collins (2007) argued that environmental education can be evaluated not to determine consistency, but to use various methods of education and learning. It may also inspire students to think about their artwork in terms of eco-art education [68], as seen in Figure 4.

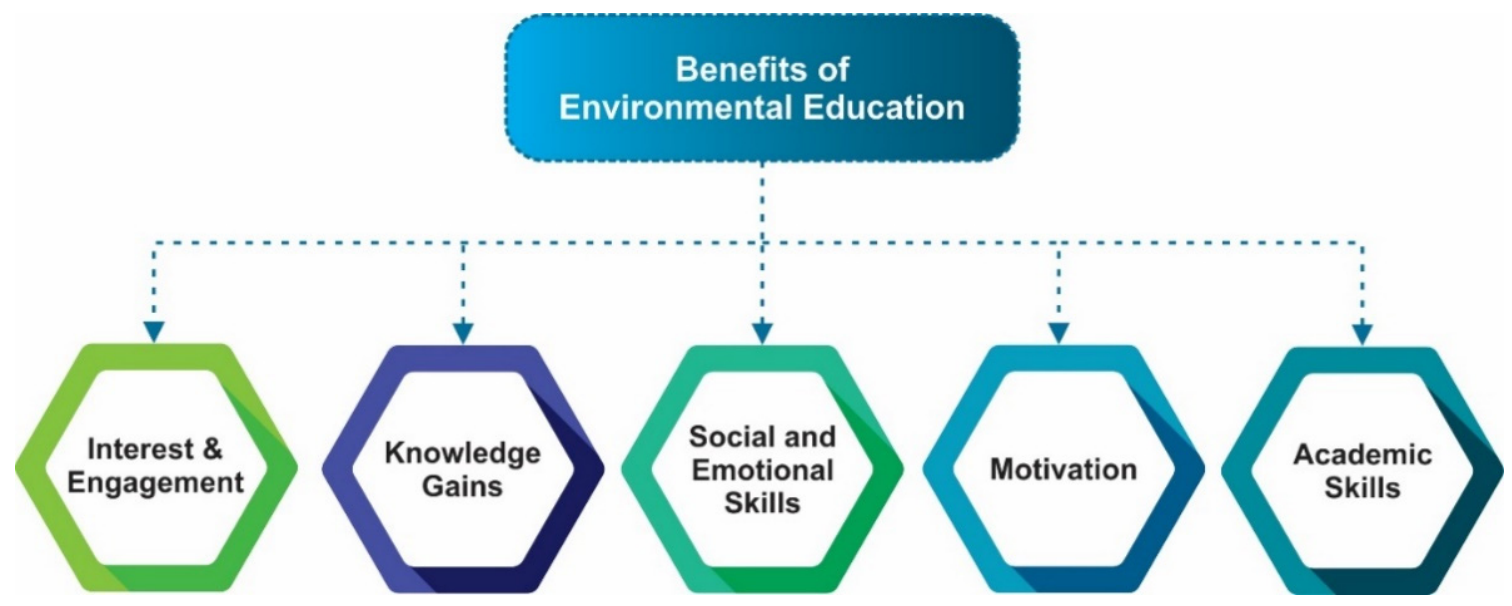

Figure 3. Benefits of environmental education (Ardoin, 2018).

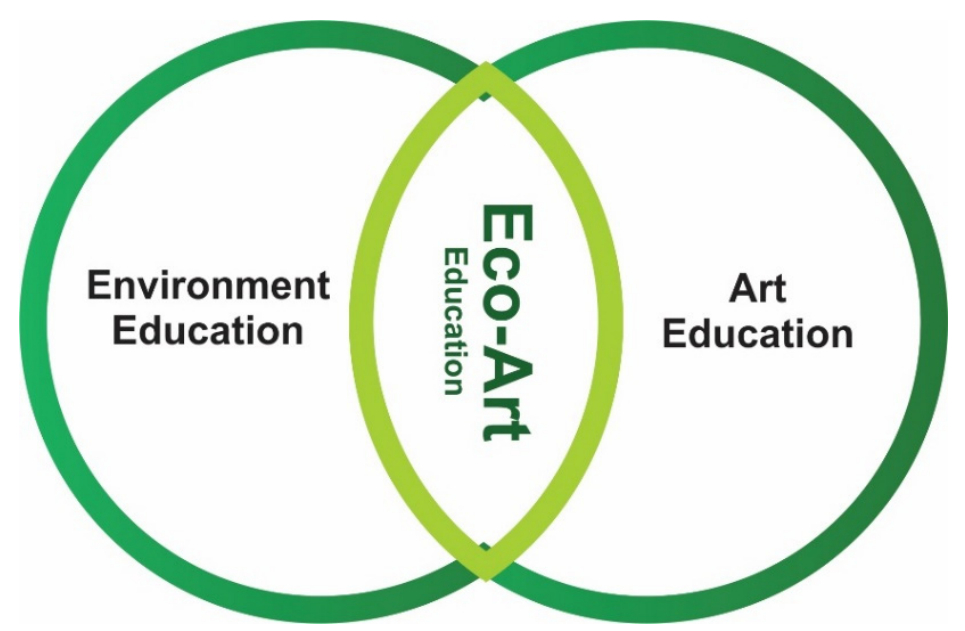

Figure 4. Eco-art education (Inwood, 2013). 


\subsubsection{The Role of Eco-Art in Environmental Education}

The use of eco-art as another evaluation enables students, by voicing their environmental awareness, to better understand and explore their imagination (Eisner 1999; Cronin-Jones 2005) [69,70]. The creative appraisal technique (Tunstall, Tapsell, and House, 2004) uses photography as an instrument for intervention and evaluation in research for students aged 12 to 14 years. The use of photography allows students to direct the inquiry process by developing a homework campaign that permits students to express their individual thoughts and feelings about common areas [71]. Students recognise aesthetically pleasing features of a region (trees, flowers, water), recreational opportunities (walking, fish, wildlife monitoring), human waste in a river (waste, pollution), and potential future improvement, based on images of a river (larger banks, wider roads, bridges) that were collected and analysed (Tunstall et al., 2004). The pictures also suggest an insufficient comprehension of the living and dying elements of coastal vegetation for children in urban schools (Tunstall et al., 2004). The visual arts, as illustrated in this example, are a different form of communication that enable students to convey ideas openly that they cannot express verbally (Lewis and Green, 1983) [72]. Students' drawings, in particular, include emotional answers to environmental concepts and challenges, reasoning, and cognitive responses (Bowker, 2007; Gardner, 1993) [73,74]. Alerby (2000) used sketches by 109 students (10-16 years old), in three categories: (1) the nature, (2) sustainability, and (3) environmental conservation. The statistics demonstrate how the climate and the environmental destruction of intact ecosystems, waste, and biodiversity can be preserved (Alerby, 2000) [75]. Barraza (1999) also studied 741 pictures portraying the experiences of students' (7-8 years of age) hopes and fears for the future. The study showed greater similarities than the diagrams: $90 \%$ drew a representational picture of the planet from space, $54 \%$ were able to render the future Earth as ecologically worse than it is today (Barraza 1999) [76]. The study is more similar than that of the sketches. In addition, before and after the Trekking Program, Bowker (2007) compared students' pictures of rainforests (10-13 years of age). Pre-test sketches showed trees and plants out of sight, while in the foreground there were rainforest creatures. Drafts using the software consisted of different creatures, with most pictures being informative drawings of tropical plants (Bowker, 2007). The above three studies have shown that drawings can complement the environmental perception of students and that they are a good environmental education approach. Experts have claimed, however, that art-based evaluations are highly contextual, subjective, and difficult to evaluate. Two separate approaches to boost image scoring are rubric scoring and observation (Cronin-Jones 2005). The titles in scores offer a clear evaluation of the drawings that can be adapted for any object or environmental aspect. For example, Smith, Meehan, and Castori (2003) used the drawings of 12-15-year-olds to evaluate the relationships between students after their exposure to animals and produced a rubric that includes four correlation criteria to evaluate students' drawings:

(1). Positive, negative, or neutral;

(2). Direct, indirect, or non-interactive;

(3). True distance;

(4). Real or absent.

The use of grading and students' drawings has effectively shown how the behaviour of eco-art education has developed (Smith et al., 2003) [77]. In order to assess the drawings of 11-16 pupils, Cronin-Jones (2005) developed score lists concerning their interpretation of the habitats of the schoolyard using a five-point scale and seven-point rubric to test students' drawings. The analysis indicated that using a rubric is efficient for qualitative study (CroninJones, 2005). This technique has been endorsed in various studies (Hoot and Foster, 1993; Wilson, 1993) by the use of drawing and painting in eco-art education [78,79]. However, minimal evidence is available to support the use of drawings as an important method for the assessment of environmental education. Cronin-Jones (2005) asked students to write down their views, emotions, and assumptions regarding their drawings, thus helping 
teachers to distinguish the difference in students' environmental awareness and attitudes between their pre-test and post-test scores.

\subsubsection{Eco-Art in Nature}

In 2003, Smith et al. proposed that students should study in nature. Eco-art in nature is a natural resource eco-art initiative which aims to increase public consciousness of environmental concerns. The beautiful sculptures employed consisted of colourful leaves, petals, branches, or stacked stones. The focus was mainly on the processing of artefacts, literal change, or the discovery of common materials in the environment. This form of art is connected to nature's beauty and tackles environmental problems. Some initiatives include the use of felled trees, maceration, or "permanent" museum and sculpture park structures. Art in nature may directly involve the public in gathering stones or in creating temporary forms on beaches or in public areas, encouraging the public to develop a link with nature, thus promoting a deeper connection with it.

\subsubsection{Ecological Art}

Sustainable art is sometimes called environmental art. This work deals specifically with environmental concerns, often including collaboration, field recovery, and methods and methodologies that are "environmentally sound". This kind of environmental art is also interpreted specifically through its potential to serve societies and ecosystems (Greenmuseum, 2010). Environmental art facilitates reflection on the world in which we live, encourages dialogue, produces innovative minds, and fosters social change, enabling the diversity of the Earth's life structures to evolve (Gradle, 2007) [80]. Environmental art leads to environmental consciousness and environmental conservation. Artists develop new ways to change people's minds and increase their understanding of the world. Some of them are regarded as artists of the environment. Ecological art has been described in various ways. Greenmuseum.org uses the term "environmental art" to refer to "works of art created by artists that are concerned in the context of our environment and its emergencies around the world" (Greenmuseum 2010, 4). Others describe environmental art as a movement created to increase awareness, dedication, and proactivity in the process of addressing environmental concerns through conservation art (Blandy 2012) [81]. The characteristic aspect of environmental art is, according to Barbara Matilsky (1992), the relationship between art and nature [82]. In addition, she claims that environmental art should not separate, perceive, or incorporate elements of nature in absolute networks. Examples of eco-artist Professor Basia Ireland and Hull's investigations can be found at Greenmuseum 2010.

\subsubsection{Designing Successful Eco-Art Education Pedagogies}

Inwood (2008) accepts that "There is an education that is experimental, multidisciplinary, interactive, dialogical, ideological, and builds on the values of empathy, tolerance, and respect of the environment that is most suitable to learning in the environment of eco-art" (Inwood, 2008, p. 34). Gude (2013) argues that creative projects give students the opportunity to dive into problem-solving and interact meaningfully with their lives [83]. Garoian (1998) connects environmental education pedagogy with compassion and sympathy. He felt as a teacher that it is important to educate and inspire his students to express their ideas and concerns regarding environmental issues [84]. Perhaps more importantly, Garoian indicated that he knows how to implement sustainable practises that can be integrated in the lives of students and communities. Simon (2006) concentrates on art education and learning, but the approach focuses more on the way environmental artists investigate structural dimensions of environmental issues [85]. This research involves networking projects touching on participants' beliefs and experiences and supports educators and artists who pursue a more collaborative approach to teaching, aiming to provide conditions that stimulate people's interest in learning. He states that ecological art has become increasingly integrated and participative, with the outcomes of such projects being able to support scientists. Graham (2007) strengthens the feelings of Simon by explaining the 
need for place-based pedagogy and offers a background of environmental art educational theory and practice that reflects the ethical attitudes towards oneself. Place based learning allows students to become friends and build interests related to their curriculum in schools. Place-based education aims to enhance children's ties with other citizens, regions, and nations, combatting the isolation and detachment that are often said to be related to modern society (p. 377). Graham stresses that a curriculum for arts education will inspire students to discuss environmental and social issues. In his research, Gude (2013) indicated that successful eco-education pedagogy should be promoted, including:

Art-making: This pedagogy involves media work and experimentation with approaches and concepts. There is no clear objective to be accomplished. Early on, arts projects such as this were important because he and his students experimented with various methods, which allowed his students to find better ways to create meaning and excite empathy. He said that eco-education alongside artistic development is required because it takes students closer to nature. The first phase was art production with 30 students. The students displayed elements of art and design, graduation of colour, sound and tone, and observational layout.

Study of environmental problems: Gude emphasised the importance of educating students internationally. He included part of an educational plan to achieve this in his work, where he watched a series of films explaining environmental issues, the consequences of pollution, and the effects of deforestation and waste. This led to a discussion with his pupils. He stated that eco-art education aims to encourage students to practise environmentally friendly behaviour in their real lives.

Attentive living: This is another phase of the teaching principles of Gude, which are directly linked to such study. He argued that students learnt about the atmosphere and nature through observation: "Or making a gardener would make the student realise that creative thought is inseparable from daily life but that it can teach and improve all aspects of the life of an individual" (Gude, 2013, p. 5). Students must observe, draw, and create objects in nature in order to appreciate nature's beauty. Students will also explore a nature trail, where people endanger a world full of character. Gude expresses his plan as an approach which takes into account students' multiple visual presentations and makes it possible to engage students. School observation and preparation is where the discovery begins.

Social space reconstruction: Gude describes how to create a social space which gives students a door to the outdoors through which they can connect with nature. He calls on art teachers to build a network of art and work with students to create new spaces in accordance with this theory.

Believing: Gude honours art teachers and students who have a strong personal commitment to modern education programmes. Students were granted the freedom to create their own theories. Some of their realities were in some way changed. Some educators were inspired to "show the positive components of the field in which they are motivated to create art" by emphasising eco-art education (Russell and Hutzel 2007) while the student works in their field (p. 9) [86]. Gude (2013) proved this by pointing out that teachers need to provide instruments to help students understand and find mechanisms to engage in the world. Furthermore, Gude pointed out that "we must recognize an eco-artistic education based on the facts of life's environmental challenges and the realities of the present school environment" (Gude, 2013, p. 9). We must teach our students to resolve problems and make them aware of the world (Gude, 2013). Eco-art is a celebration of nature and an approach to enhance our daily environments (Gude, 2013). Gude (2013) claims that students learn best by learning about eco-art. Gude (2013) suggests that pupils should be completely trained to use all of their senses. It is necessary to incorporate this lesson in eco-art education through direct observation, study, and the use of environmental information. In his thesis, he explored how students can change their minds and learn to understand nature through education in the field of eco-art. The study techniques, including drawing and observation, are qualitative and quantitative. He built a software for his test intended for a student 
aged 12-13. He introduced students to three topics in his designed curriculum: Harmony, Place and Transformation (Graham 2007), so that they can become aware of current environmental concerns. In their study, Upitis (2007) quoted some examples of successful pedagogical methods for the advancement and promotion of the ecological interest of students [87]. The study included students between the ages of 13 and 16 years. Here, the student planted, harvested, and prepared food, health education, and eco-learning. He said that flowers are effective in setting ecological emphasis by involving students in planting. Analysing artist Ruth Wallens' Children's Forest Trail (1996), Rosenthal (2004) describes that in her interactions with her students, Wallen has combined artworks to include pictures, artefacts, sounds, or text, and built state-of-the art montages to enable them to see new opportunities as a result of their investigations (Rosenthal 2004) [88].

\subsubsection{The Benefits and Students' Outcomes of Integrating Eco-Art Education}

A large number of opportunities are provided by art and environmental education, which can change the way in which environmental education is thought about. However, at times, goals can feel so unreachable that students may feel that they do not have the power to change things. However, students can change things by expressing themselves in a physical way, such as creating art pieces or integrating visual arts with environmental education (Song, 2008). Art education also has the power to solve environmental issues, because it can convert the complex issues of the world into more understandable and relatable things (Blandy and Hoffman, 1993; Inwood, 2008; Inwood, 2010). It has been proven that a large number of positive things can be brought about by environmental education. An increase in creativity was seen in students involved in an eco-art education programme (Inwood, 2008; Inwood, 2010, Lankford, 1997) [89,90]. A high level of interest was shown by the students in raising awareness, expressing themselves, and discussing issues related to ecology (Lankford, 1997, 50). A basic and initial perspective of environmental issues can be created in the minds of students with the help of artworks. Creating solutions and making meaningful things with the help of artwork is something that is taught to students in environmental education. This education also makes it possible for students to connect on an emotional level (Holmes, 2002; Anderson and Guyas, 2012) [91]. The ability to feel and think about nature in a more constructive way can be brought about by eco-art education (Song, 2010, 96). It gives students a way to connect to the environment on a more meaningful level, which leads them to improve their relationship with nature and the environment (Song, 2012) [92]. Putting more importance on connecting with the environment on an emotional level increases the ability of students to understand themselves and the environment (Rosenthal, 2001) [93]. This also helps students to better understand, care for, and respect the environment (Wallen, 2012). Examples of direct experiences that people from their own community have had are also provided to students to give them a more personal connection to the environment (Wallen, 2014). Experiences that were had by students while undertaking an art project were expressed in Song's research (2010). The main aim of the project was to address the problem of plastic pollution. Some drawings of these issues were presented by students. The drawings were of a fish caught in plastic bags and a bird that could not move due to its leg being caught in plastic. This project made the students feel strong enough to express their opinions on these issues using their own skills. It gave them the power to act upon the issues about which they were passionate (Song, 2010). Graham (2007) also discovered that an opportunity to directly learn through exploration was given to students who drew natural objects. The creation of art by students offers them a whole new level of understanding of nature (Anderson and Guyas, 2012).

\subsection{Place-Based Education}

Connecting places, people, networks, and environments is the main objective of placebased education (PBE). It is important to understand the definition of place and the way it is defined in the philosophies of education in order to understand the use of place in education. It has been stated that places are areas that have a meaning and purpose and 
that they are a product of the development of humans. Meanings are given to places by the connections that they have with people on a personal level. Gruenewald (2004) stated that the end goal of place-based education was to influence students using their day-to-day experiences, and also invoke their inner ecological creativity. To make education more relevant to real-world situations, it can be helpful to provide students with real-world experiences, thus making them better suited to take care of and protect their communities. The author also stated that place-based education increases students' empathy for nature and their concern for the environment (Gruenewald 2004) [94], as shown in Figure 5.

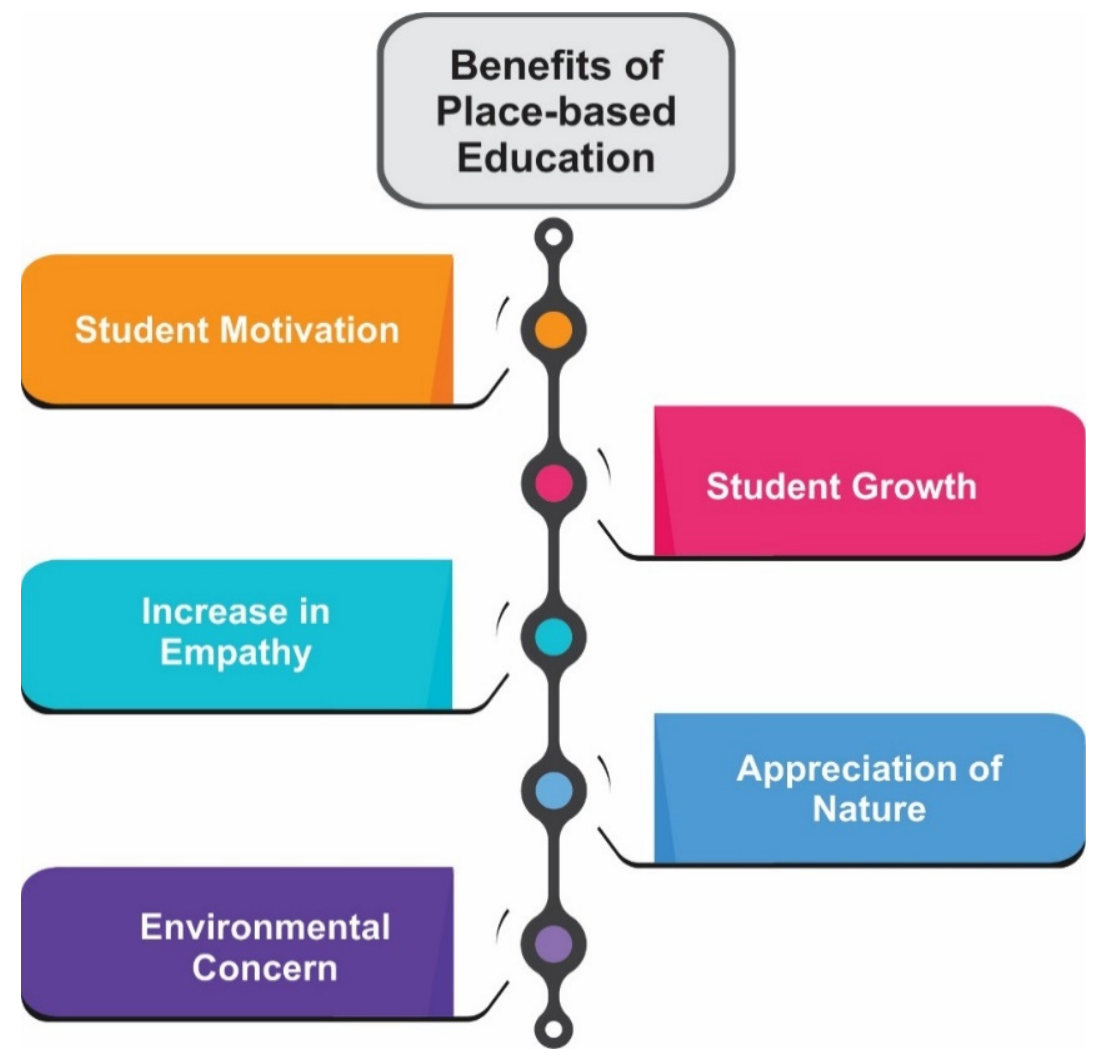

Figure 5. Benefits of place-based education (Gruenewald 2004).

The first experiments on place-based education took place in the 1990s (Knapp, 2005) [95-99]. It was found that place-based education fits well alongside art education. Inwood (2008) further elaborated on the benefits space, art, and environmental education can offer each other; a method to invoke inner creativity and encourage appropriate ecological behaviour by connecting to the world around us has been provided by these three forms of education (p. 70).

\subsubsection{Critical Place-Based Education and Place-Based Education}

Gruenewald 2003 had brought forward ideas to tackle the issues that were associated with place-based education-For example: studying outside the home environment and exploring the neighbourhood. Place-based study that goes beyond the classroom exposes the students to real-world scenarios, making them better equipped to handle those situations and ultimately helping them to overcome environmental issues (Smith and Sobel 2010) [100]. The idea of engaging in something and making their voices heard is also something which place based education studies greatly help (Smith and Sobel 2010). David Gruenewald (2003), by suggesting a mix of essential instructional methods, created an outline for the restrictions of this kind of system of education. In order to take students to the front lines and connect them with the rest of the world, place-based education is crucial. Gruenewald (2003) combined two methods of instruction when he 
put forward a place-based instructional method based on place-based education to bring about the change that he wanted to see. Graham (2007) stated that the need to learn how to deal with out-of-school encounters was supported by the place-based instructional method (p. 379). As Smith and Sobel (2010) demonstrate, students and educators who can associate natural issues with social issues are the best delegates to advance ecological mindfulness and social prosperity through their convictions, mentalities, and exercises. This sort of instructional method is important, because it diminishes the predominant powers in place-based education and supports the social and ecological prosperity of a place (Gruenewald 2003). Wakeman (2015) proposes that place-based essential education goes beyond place-based education by looking at the kind of education that is appropriate for building a solid connection between the climate and art in an education framework $[95,96]$.

Research has shown that many students are unaware of their connection with nature, and that students in urban settings never receive focus. This indicates that students do not like to learn in outdoor settings (Dillon and Dickie, 2012) [97]. Fjortoft (2001) suggests that students like to play in local natural environments (as cited in Allison, 2013, p. 194) $[98,99]$. Researchers have suggested that creating regular positive habits in nature will help students develop respect for the environment (Ernst and Torquati, p. 194) [100]. Research shows that when students are engaged with the outdoors, they tend to show more value and care for the environment (Dillon and Dickie, 2012). Exposure to the outdoor settings helps student learn about their relationship with nature (Quay, 2013, p. 143) $[100,101]$. Beames and Ross (2010) recommend that it is these experiences that build an "increased connection with the students' surroundings" (as cited in Fagerstam, 2014 , p. 59) [102,103]. Developing connections to natural settings, strong local ties to the environment, learning outside classroom walls, and attachment to the outdoors are significant aspects. Research shows that those students who have direct contact with nature, show more willingness to protect the environment (Dillon and Dickie). In place-based education, "developing direct contact with nature and place lead to greater care for the environment" (Waite, 2013, p. 425) [104].

\subsubsection{Students Developing a Connection for Nature and Place}

When students have positive experiences with nature, they can develop connections with and love for nature and space. It is extremely important to take students out of the classroom for observation; allow them to discover their intelligence; and then let them develop empathy, emotion, and respect for nature and create art in neighbourhood settings (Inwood, 2011 and Song, 2010). Pamela Michael (2005) discussed her "River of Words" project and stated that its main goal is to help students interact with nature using all their senses: "Students protect what they love and feel" (p. 116) [105]. Cheng and Monroe (2012) also make use of Michael's words, such as "spending more time in nature helps students to bond with nature and guide them as protectors" (p. 45), "the connection with nature is solid", and a "Predictor of students' interest in ecological practices" (p. 45). Chiras (2005) propagates this idea by noting that the nature of young people's experiences with the natural world and the duration of time they spend in nature are important [106]. Graham (2007) argues that "for younger students experiencing the beauty of the world, Recognition is an important step toward environmental responsibility" (p. 380); Sobel (1996), as an environmentally responsible citizen, states that students must learn "to love the common world before it is asked to heal their wounds" (p. 380) page 14 [107]. Rodenburg (2017) reports that teachers often overload students with data on environmental issues without taking into account students' interest in such issues; this makes students feel powerless and does not inspire them to act [108]. Rodenburg (2017) suggests that teaching students about environmental issues can be a complex and tedious experience for them. Using place-based education in conjunction with eco-art education can make the topics covered interesting and engaging for students. Sobel (1991) points out that it is impossible for students to take measures to protect their environment if they do not like living spaces and communal areas (Sobel 1991). Story telling helps to create relationships between students and their 
families. This is because children love stories; therefore, teachers can take into account location in environmental matters to give students an idea of their relationship with their neighbourhood (Rodenburg 2017). Somerville (2010) lays the foundation for this reality by revealing the characteristics of stories, such as the words, imagery, and images, which are attractive to students [109]. In the field of environmental education, place-based education responds to the need to provide students with care for and experience in nature so that they respect the world (Sobel, 1996). This has been hailed as an educational process that "encourages students to develop stronger bonds with their place and increases students' appreciation of nature" (Sobel, 2004, p. 7). Eco-art can contribute to the development of a love for nature in students. Michaels (2005), Inwood (2008), and Song (2008) believe that the subjective, emotional forces of eco-art education can add "heart" to the experiences of nature and help students make emotional and cognitive connections that can contribute to attitudes and behaviours that lead to thinking about the environment.

\subsubsection{Eco-Art Education Encouraging a Place-Ethic}

Place-based education in eco-art education focuses on both the social and ecological environments where learning takes place. David Sobel (1996) suggests that teaching concepts in environmental education using neighbourhood locations such as ecosystems or watersheds provides students with context for what they learn. Sobel (1996, p. 10) argues that before asking students about the wounds that need to be healed, it is important for them to have the opportunity to connect with the world, learn to love it, and learn to feel comfortable in it. As arts educators develop a sense of place in students that encourages them to connect with the distinctive world and is based on the network's resources and context, these students will not only develop a sense of where they are, but also be interested and develop care for other places, and this will lead to them caring for their environment. There are several studies showing the experiences in nature that will have an impact on students' ethics, attitudes, and environmental behaviours through eco-art education (Chawla, 1998; Huby and Bradshaw, 2006) [110,111]. John Cameron (2003, p. 99) promotes the notion of the "sensibility of the place" by maintaining "the creative tension between deep experience and basic consciousness" in a place and argues that eco-art education plays the most important role in promoting this [112]. He suggests that place-based education is an important method that builds and helps maintain a rich and deep connection with the environment. Regarding place-based ethical education, Cameron (2003) asserts that he combines the importance of in-depth experience with basic awareness. This also highlights the importance of incorporating eco-arts and place-based education to provide schools and teachers with valuable opportunities to embed environmental learning using easily accessible resources.

\subsubsection{Place-Based Pedagogy and Art Education}

Blandy and Hoffman (1993) suggested that art education is closely related to placebased education. However, arts education is the backbone of place pedagogy in primary school according to Graham (2007). A place-based arts education curriculum requires three components: normal history, social reputation, and transformative education. Within his historical era, Graham (2007) described plant drawing, plant communication, and community planning as approaches to connect with the ordinary world. Such exercises can help students to interact with nature; however, as Garoian (1998) calls attention to, these exercises can add to the development of ecological issues. Along these lines, instructors ought to urge students to become familiar with the recorded exercises. In this instructional method, students are instructed with the investigation of visual culture. This pedagogy was adopted because of the creation of place learning, its importance in helping students to establish their first contact with nature, and to take into account a key component. 


\subsubsection{Eco-Art Education Related to Place-Based Pedagogy}

Place-based eco-art education offers students the assistance to learn outside of school and protect the environment. It shows that the works of eco-artists, consisting of photographs, drawings, images, and interactive showcases, are designed to change our view of nature (Solnit, 2001) [113]. His work forms the boundary between ecological art and ecological research, while collaborating with scientists and engaging in ecological research and environmental regeneration. Eco-art shows concern for the environment, and is prepared by artists (Taylor, 2002) [114]. The involvement of students in this type of artwork and practice connects eco-art education to important issues in the immediate context of students' lives and encourages them to be environmentally friendly. Eco-art education can encourage network reconstruction, help define a common personality, and improve environmental responsibility (Anderson, 2000; Blandy, Congdon, and Krug, 1998) [115,116]. A study conducted by Anderson, 2000, where he evaluates children's environmental knowledge and attitudes before and after a place-based experiential environmental art education curriculum, comprises five lessons. The lessons concern the issues of environment, environmental issues, harmony, place, and transformation. The research was conducted with 11th and 13th grade students in a combined class. The focus for the lessons was the school garden, because this was an accessible natural feature used to conduct place-based learning for students. The objective of the study was to use the results of outdoor environmental education as a tool to positively affect 11th and 13th grade students' environmental knowledge of and attitudes toward the environment. The data were collected using qualitative and quantitative methods. The qualitative methods included interviews, focus group interviews, and observation. The quantitative methods included a statistical analysis of environmental knowledge and attitudes through pre- and post-knowledge tests and assessment using the Model of Ecological Values (Bogner and Wiseman, 1999) [117]. The curriculum and lessons focused on three main themes: harmony, special place, and transformation. These lessons were taught from February 2016 to April 2017. The environmental art comprised two main components: each student drew their own design of a property they wanted to build along with the ideal school garden. The drawings were independent art projects that the students created at home and then brought into class. The students designed and later painted directly on a $55 \times 50$ inch canvas that was then displayed on a wall at the entrance of the school. They evaluated the fact that students reported that experiential learning lessons greatly helped them learn concepts. Their findings led them to conclude that the environmental education curriculum significantly influenced students' environmental knowledge and that the mural creation process was the most meaningful of the art components to the students. They also found the environmental issues students were most concerned about after completing the curriculum, and that environmental art education in a place-based pedagogy positively influenced students' environmental knowledge and behaviours.

\subsubsection{Effectiveness of Place-Based in Eco-Art Education}

Studies have shown that students consistently make use of a place-based methodology (Powers, 2004; Takano et al., 2009) [118]. Research has been carried out to find more effective place learning outcomes among 13-16-year-old students in eco-arts education. Buxton's (2010) research focused on environmental knowledge and awareness among students during a summertime science programme [119]. As his theoretical basis, Buxton used Grunewald's (2003) theory of place pedagogy that controls environmental issues and dwellings. Environmental concerns include the awareness of damage and rehabilitation (Buxton, 2010). The qualitative component of this blended study examined students' ability to be proactive in solving environmental problems and reuse living spaces. Using a parallel approach to structure and design, Buxton qualitatively analysed pre-test and post-interview interviews using open coding and scoring rubrics. This outline allowed him to pinpoint the change in student responses by examining the results with the rubric and analysing the depth and breadth of the responses through qualitative research. The research of Buxton (2010) also focused on environmental behaviour, attitude, and student 
awareness. It examined the use of blended methods, such as observations, interviews, drawing exercises, and questioning, and the impact of domain-specific curriculum on students from different socio-economic and racial backgrounds. Buxton identified a large difference between male and female students' assessments before and after the survey and found a positive effect on students' behaviour and attitudes towards the environment. These results show that participation in the programme in a particular place hugely affected students' ecological behaviour. In addition, the research used a robust comparison method based on the use of grounded theory for a study using mixed methods (Glaser and Strauss, 1967) [120]. He used three types of coding in his qualitative research: the open coding of information; line by line coding to encode each event in one observation, as well as to indicate each line of information in other sources of verbal information; and axial coding to compare topics across each set of quality information. These codes included: a sense of nature, understanding of nature's beauty, the development of feelings, and unity with nature. The third used selective coding to integrate categories and topics in such a way as to formulate a coherent understanding or theory of the research phenomenon. Using these codes, he created research criteria and identified links between categories. The criteria that emerged from the knowledge included varying issues, changing individual responses. The quasi-experimental blended study examined the impact of the curriculum on students aged 10-13. Conaway developed his own questionnaire to measure students' level of knowledge and beliefs regarding the environment [121]. He used quantitative methods before and after surveys to measure place identity and place dependence, as well as qualitative methods before and after meetings. Both statistics showed that students did not develop a stronger attachment to a place in the 13 weeks they were taught by Cook's students. A study by Takano, Higgins, and McLaughlin (2009) examined, among other things, the relationship between high school students and the ground in a longitudinal study using mixed methods. Pupils in grades six through twelve attended a local school in a modest community. Takano et al., based on a 2002 study, found that a place-based curriculum influenced students' views of the environment. Some described nature as "a home, a special place"; others said that they discovered "peace, happiness, harmony" on Earth; while others said they "love, give, and appreciate nature" (p. 362). During the study, all the students interviewed reported that they felt a greater bond with the countryside. This longitudinal study is said to show the long-term impact of a place-based program. The effectiveness of place-based learning with a wide range of learners suggests that a place-based arts education programme could be effective [122,123].

\subsubsection{Students' Outcomes in an Eco-Art Place-Based Education Program}

The literature on place-based learning shows that this pedagogy can help students to appreciate their environment. Two phenomenological studies (Gradle, 2007; Triggs, 2009) examined students' place-based experiences in eco-art programmes [124]. The research suggests that place-based learning can be an effective tool to help students discover a sense of place and explore and expand the discourse around being in one place (Gradle, 2007). Another study of place-based arts education programmes with students is the study of collaborative activities (Creel, 2005) [125]. As an art teacher in elementary school, Creel worked with ninth-grade students with "at-risk tendencies" in an environmental arts education programme that met the criteria for place-based arts education. During the study, Creel described the difficulties students faced due to their families' financial situations and other risk factors. In this program, the students, students from other schools, and the network worked together to create an ecological sculpture garden. The strength of this study lay in its use of various methods and extensive interaction with these students. More research is needed to examine the impact of environmentally friendly pedagogy in arts education on K-12 students. Although a study by Creel (2005) showed positive changes in environmental awareness and empathy, his students were only in the ninth grade. He said that research was needed in order to investigate the effectiveness of such a programme with other targeted meetings. In addition, it may be particularly necessary to 
evaluate this population. The limitation of this abstract idea will be significant, because it is often presented together with idealism and an awareness of possibilities (Santrock, 2001) [126]. Selman (1980) also argued that students aged 10 to 15 are more successful in environmental education programmes than older students. Sobel (1997) defined this 10- to 15 -year period as the main period in which to develop communication between students and the land.

\subsection{Empathy}

Empathy for the normal world is worth exploring as a possible outcome of placebased education programmes for the arts, because place-based education programmes produce positive emotional outcomes in relation to the environment and empathy is closely related to the arts. Empathy can be distinguished from compassion and sympathy. Compassion generally involves the recognition of "negative emotional states (like pain) and then experiencing an urge to help" (Zaki, 2017, p. 3) [127,128], as shown in Figure 6. Compassion "refers to the process in which we feel together and how the other feels (in this case, torture), at the same time that the other feels. In this way we ourselves are what we perceive in the other" (Zaki, 2017, p. 33). Empathy, on the other hand, refers to understanding what the other is feeling and thinking while distinguishing others from the self. Vignemont and Singer (2006) argue that empathy "is simultaneously a cognitive and affective process" (Coplan, 2014, p. 5) [129].

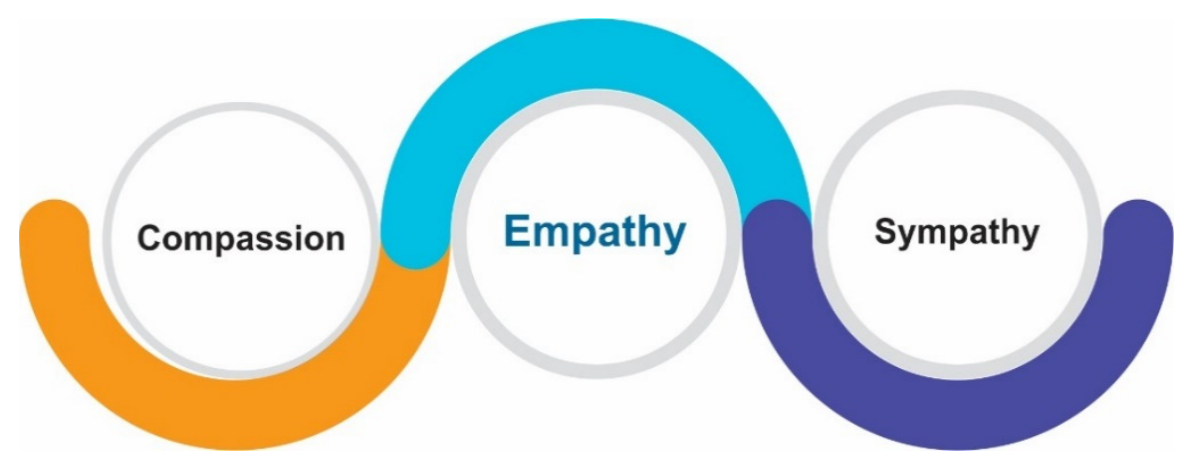

Figure 6. Empathy (Zaki, 2017).

\subsubsection{Empathy with Nature}

As shown in a hypothetical system, compassion is not only limited to sympathy between people, but is also identified with nature. Sobel (1997) explained that one of the main purposes of environmental education is to help students learn to empathise with nature. This goal is important, given the link between sympathy and more conscious natural perspectives and supportive ecological tendencies (Berenguer 2007) [130]. Carlegger and Cervinka (2009) showcased research on understanding the connection between nature and beliefs. As the distinguishing feature of this study, they analysed the relationship between environmental concern, which they called "closeness to nature", and positive environmental attitude. Using the Nature Relations Scale (CNS), they rated the closeness of 178 elective students to nature and supported ecological aspects using the New Ecological Paradigm Scale (NEP), finding that CNS scores were mainly related to NEP scores. These discoveries confirmed the link between the two focuses of this research: climate empathy and environmental benefits. Batson's altruistic and prosocial model of behaviour (Batson, 1991) suggests that increased compassion can improve environmental behaviour [131]. This model concerned two of the research studies of Berenguer $(2007,2010)$, in which the author attempted to determine the relationship between empathy and pro-environmental behaviours, and moral reasoning. In both studies conducted by Berenguer $(2007,2010)$, a factorial design $(2 \times 2)$ (two high/low empathy $\times$ two objects of empathy/bird) was used to determine the relationship between empathy level, empathy object, and either pro-environmental attitudes and behaviours (2007) or pro-environmental moral reason- 
ing (2010). In these studies, he suspected that students who were encouraged to feel a high level of compassion for the environment would come to express pro-environmental attitudes, behaviours, and reasoning. In a 2007 study, participants were trained to analyse an image of an object of empathy (oil-covered birds or chopped tree stumps) while remaining objective (low empathy state) or accepting the object's point of view (high empathy state). The students then filled out a questionnaire to measure their empathy level. Berenguer discovered that those who were very compassionate needed to show empathy for the environment to solve environmental problems during this research. The increased empathy then encouraged stronger ecological attitudes and behaviours. Moreover, in a study by Berenguer (2010), students were given tips to help them increase or decrease their empathy for a person or an animal. The participants' responses were described as anthropocentric, eco-centric, or non-environmental. The study result was positive, with an especially high level of sympathy shown. It was found that when the object of empathy was an animal, the participants' arguments were more eco-centric, and when the object of empathy was a human, the participants' arguments were more anthropocentric. This research established a strong link between the empathy initiated and support for ecological thinking. Both studies suggest that helping students develop empathy for the environment promotes environmentally friendly behaviour $[131,132]$.

\subsubsection{Empathy and Eco-Art Education}

Articles on empathy and artistic experience show that empathy can be associated with art education. In addition, the previously described work of Creel (2005) has convincingly demonstrated the existence of empathy in the place-based art classroom. However, more research is needed when designing educational programmes, especially because empathy is an important part of an enjoyable experience. Creel supervised 13-year-old students who experienced empathy in place-based education. In her review, she described some factors contributing to empathy for the environment in her findings: experiencing the world directly, opportunities to care for nature, and opportunities to affect environmental change. These contributors allowed her to discover that students' empathy for the environment was high. Eco-arts education can be the perfect place to turn this response into extended empathy. In particular, a place-based methodology can be ideal because its main goal is to promote connections. Critically, place-based education offers excellent opportunities to develop empathy in students.

\subsubsection{Empathy and Aesthetic Experience}

In spite of their ecological outlook, practice, and relationship with promoters of good reasoning, empathy is firmly connected to aesthetic experience. Vernon Lee wrote in 1912 of how "bodily resonances" could sharpen and focus an aesthetic experience because the body and mind are engaged (as cited in Lanzoni, 2009) [133]. Numerous investigators today accept that empathy is an aesthetic attitude and experience (Franklin, 1990) [134]. Be that as it may, the research by Koss (2006) on "a pattern of excitement, feeling and psychological projection" (p. 1) in empathy could more readily depict the nature of the process [135]. Empathy is a means to inspire feeling and empathy for nature. In an aesthetic experience, the viewer's construction of representation could best be described as a dialogue occurring between the viewer and the artwork. White (2009) investigated this connection between the eyewitness and the object of dominance [136]. As a sign of this relationship, both have an obligation to the following and should bring something essential to a pleasant encounter (as noted in White, 2009). Oremland (1984) characterised dominance as "understanding the viewer's empathy" (pp. 239-240) [137,138]. Empathy is an essential part of this discussion. For instance, Hoge (2003) found that when bringing students to a museum, they revealed feelings of compassion when seeing the artworks [138]. In line with this view, Freedberg and Gallese suggested the critical role that physical and emotional imitation plays in developing empathy during an aesthetic encounter and the students' reaction to an artwork (Freedberg and Gallese, 2007) [139]. 
The second the replacement entertainer sees the show stop, the body reacts with a modified impression. This impression can emerge from the subject according to the type of execution. For instance, when a student views a work of art, the body responds through an automatic impression. This impression can occur in response to the subject matter and form of an artwork. For example, when a student observes an artwork, particularly one where the gestural qualities are evident, the student's brain attempts to reconstruct an imitation of the action that the artist undertakes to create that gesture. Gallese (2004) suggests that artworks can create embodied empathy.

\subsection{Pro-Environmental Behaviour}

Pro-environmental behaviour can be characterised as an application generally characterised and demonstrated by the environment (Iwata, 2001) [140]. The expression "ecological behaviour" can be thought of as a behaviour that is generally shown as a defence method in natural behaviour. This supports ecological practices, which are described by Kollmuss and Agyeman (2002: 240) as "behaviour that deliberately tries to limit the negative impact of its activities on norms and climate" [141]. In addition, the ecological mind set refers to people's emotions and concerns about certain elements of the environment (Holahan, 1982) [142]. Scientists such as Schultz (2001) admit that people's views of and fears about the environment stem from seeing themselves as a feature of nature [143]. He agrees that a person's attitude towards the environment depends on his quality rating. He adds that people with different value orientations will have different perspectives of the environment (Schultz, 2001). In terms of preparing students for affection, the usefulness of natural practices is seen as understanding their impact on the environment. This provides a better understanding of the supportive environmental practices that represent students' reactions to nature [144].

\subsubsection{Demographic Factors That Influence Environmental Behaviour}

When assessing how students behave within the environment, it is important to look at their behaviour. Likewise, it is important to examine different cultures and educational institutions and evaluate their place of residence with regard to environmental attitudes and behaviour (Bell et al., 2001; Scott and Willits, 1994) [145,146]. Various studies have shown that students of different backgrounds have different views of the environment. Researchers initially tried to clarify this distinction by focusing on factors such as education level, age, gender, socio-economic background, and place of residence as possible variables of environment attitudes and behaviour (Bell et al., 2001; Scott and Willits, 1994).

Education level: One of the most consistent findings in this article concerns the relationship between environmental behaviour and education level. Research shows that students with a high academic level often show more concern for the environment than students with a low academic level (Buttel and Flinn, 1978b; Grieve and Van Staden, 1985; Reynolds, 1992; Craffert and Willers, 1994) [147-151]. Reynolds (1992) conducted a study in which he found that high-performing students showed more caring behaviour towards the environment than low-performing students. The findings of Willers (1996) support this view. As his research shows, high-performing students have an increased level of ecological concern. Knuth (2001) adds that the instructions people receive have a similar effect on how they view their environment [152-159].

Age: Bell (2001) and Fiedeldey et al. (1998) assured that age is probably the best indicator of behaviour towards the environment [160-164]. For example, Fiedeldey et al. (1998) cited research showing that younger students indicate greater concern for the environment than older students [153]. Research by Arcury and Christianson (1990) confirms this view, and also shows that age is inversely determined by positive environmental thinking; older students are less concerned about the environment [154]. However, a study by Lyons and Breakwell (1994) studied students between the ages of 13 and 16, finding that this age exactly equates to natural problems [155]. They recognise that the positive attitudes they found could be the result of the limited age group they used in their research (13-16) 
and the different educational curricula of the different grades. They added that students between the ages of 11 and 15 were more environmentally conscious.

Gender: Gender has shown clear consistency as an indicator of environmental behaviour. The study by Blum (1987) showed that there is no difference in attitudes between the two genders, male and female, but a study by Williams and McCrory (1989) showed that girls are more environmentally conscious $[156,157]$. Research by Arcury and Christianson (1990) showed that boys are more concerned about the environment than young women. According to their findings, the differences in levels of environmental between boys and girls are dependent on the specific environmental issue being considered. Their findings showed that boys are more engaged in political behaviour, while girls show more environmentally protective consumer behaviour. Lyons and Breakwell (1994) focused on students between the ages of 13 and 16 and found no gender differences in their environmental concerns. Their ratings show the difference between young boys and girls in terms of environmental concerns. In general, girls show less concern about industrial pollution than boys. Lyons and Breakwell (1994) argued that this may be because contemporary issues are viewed as logical and innovative; they therefore suggest that girls do not know as much about these topics as boys and that this is reflected in their views. Research by Lindemann-Matthies (2002) showed that sex is a reliable indicator of environmental awareness [165]. Her research showed that support for environmental education programmes has had unexpected consequences for girls and boys. A higher percentage of girls in the class $(46.6 \%)$ than boys $(39.7 \%)$ could recognise and name more living and plant species in their surrounding environment.

Socio-economic background: Research by Lyons and Breakwell (1994) showed that students from more privileged societies are more interested in the environment than lower classes. It was found that students from higher socio-economic backgrounds care more about the environment than students from lower socio-economic backgrounds. As they point out, there may be several explanations for this difference. For example, this difference may reflect contrasts in educational effects, because upper-class parents are more likely to be educated and talk about these issues with their children than parents from lower social classes. Likewise, the difference may be the result of academic success between two encounters or reflect contrasts in schools' curricula. Taylor (1989) argued that there are social, monetary, and psychological reasons why a student from a low socio-economic background may seem to be less interested in the environment. He points out that students from lower socio-economic backgrounds tend to have poor contact with nature, live in densely populated and dirty conditions, and are less aware of dirty and congested conditions than their middle- and upper-class counterparts [159]. Bell et al. (2001) acknowledged that students from low socio-economic backgrounds do not have the power or sufficient data (knowledge) to deal with such natural phenomena. Research by Battelle and Flynn (1978) showed a weak link between socio-economic status and environmental attitudes and behaviour or concern.

Place: Place can also be seen as the most important factor in environmental behaviour. For example, Ringer et al. (2001) found that students living in a city and students living in a village viewed the natural environment differently. A few thought-provoking discoveries suggested that village students will naturally be more interested in the environment than city students (Fiedeldey et al., 1998). Lyons and Breakwell (1994) agreed that the residence of the students is associated with their environmental concerns. They also acknowledged that village students are more confident in their attitudes and behaviour toward the environment than city students. Kostka's (1976) research showed that school children in the sixth grade in the city had significantly lower environmental concern scores than students from a village [160]. Kostka acknowledged that this may be due to the students' low exposure to nature. Researchers have identified pedagogies capable of creating learning spaces within which worldviews can offer similar opportunities [160]. 


\subsubsection{Promoting Pro-Environmental Behaviour among Students}

The studies carried out by Dunlap (1991) and Scott and Willits (1994) proved that some students' main concern is environmental protection rather than other students. Dunlap also presented several reasons to support their assertion. He said that students' concern for the environment may decrease as a result of the increased government attention given to environmental problems, because they expect that the government will now take care of and fix these issues. Next, students wanted to change their own lifestyle in some aspects, such as by reusing waste, but they were not compelled to change in other areas. Dunlap also stated that students do not receive exact data about the correct behaviour changed in the way of natural issues. It also recognised that students who take charge in concern about the environment would have more responsibility concerning their natural security in view of environmentally sensitive measures. Scott and Willits (1994) provided various statements regarding students who do not have access to necessary data on environmental actions. They stated that environmental knowledge creates positive environmental attitudes and responsible behaviour toward the environment. Kuhlemeier et al. (1999) also found that students' behaviours and attitudes may have same effect with respect to environmental issues, because they differ from students who actually lack such natural knowledge [161]. This leads us to the conclusion that natural knowledge promotes ecological thinking and encourages environmentally responsible behaviour and environmentally friendly attitudes. Ultimately, this shows that positive coverage of environmental issues promotes greater willingness and triggers natural environmental behaviour. They also suggest the use of environmental education to teach learning skills and knowledge. This can also connectively focus on natural problems with one's own lifestyle. Various reviews have also focused on students who are not aware of the impact of their lifestyle on the environment. Different studies have suggested that students are not provided with the necessary skills or data to have any meaningful impact on their environment. Vaske and Kobrin (2001) showed that place-based education promotes environmental behaviour. They also view place-based learning process as creating an emotional connection with respect to a specific place [162]. As per this opinion, students who have been behaving in an environmentally friendly manner develop a genuine connection with a specific place. The results show that an environmental education curriculum should be well planned to deal passionately with the environment. Researchers have suggested that positive environmental consciousness shapes pro-environmental behaviour [163].

\subsubsection{Assessing Student's Pro-Environmental Behaviour}

Environmental attitudes help us to recognise the unexpected indicator for the practice of environmental support (Kaiser, Wolfing and Fuhrer, 1999) [164,165]. The environmental behaviour of students is regulated by their qualities and beliefs about the environment. The environmental concern scale (ECS) and NEP are used as supports for measuring pro-environmental orientations and attitudes (Weigel and Weigel, 1978; Dunlap, Van Liere) [166,167]. The EC scale and 16 Likert scales are used to investigate students' concerns regarding the environment and environmental issues. Higher scores suggest that students have more concern about the environment (Weigel and Weigel, 1978). Hence, the NEP scale indicators confirm the environmental beliefs. There are 10 things that need to be noted regarding the five-point Likert scale which was used to rate the scores ranging from 1 to 5, showing an obvious deviation, as well as "I totally agree", ranging from 15 to 50, which represents individual's pro-environmental orientation such as an anthropocentric paradigm, or dominant social paradigm (DSP), and an eco-centric paradigm, or new ecological paradigm (NEP). However, the total scale score ranges from 10 , indicating an endorsement of the DSP, to above that, indicating an endorsement of the eco-centric. A score of 30 indicates a neutral stance between the two opposing paradigms (Dunlap et al., 2000). The neutral position of scores indicates 30, which lies between the two conflicting ideal models (Dunlap et al., 2000). The specialists Rodenburg J., and Bell N. (2017), were involved in the 2010 Berenguer study, which dealt with the study of the impact 
of empathy on moral reasoning regarding the environment. The following predictions were derived from this study:

Prediction 1: Students who are in a state of high empathy have a greater number of moral arguments.

Prediction 2: Students with a high empathy condition compared to those with a low empathy condition will show a greater number of eco-centric moral arguments when the object of empathy is an animal.

Prediction 3: Students with a low level of empathy are unlikely, compared with students with a high level of empathy, to exhibit more anthropocentric moral arguments if the object of empathy is a person.

According to the study, the components of empathy tend to influence the moral value of beliefs about the environment. When the opportunity is increased state of empathy for an animal, students would limit the use to a more eco-centric mind-set. Consequently, there is increased state of empathy for people, resulting in students tending to use more anthropocentric reasoning. The study of Sherburn and Devlin (2004) stated that the use of the Environmental Preference Questionnaire (EPQ) (Kaplan, 1977), the NEP scale (Dunlap et al., 2000), and the EC scale (Weigel et al., 1978) was involved in the evaluation of students' pro-environmental behaviour support between the ages of 12 and 15 [168,169]. The results of the study found that students in that course of environmental studies were more concerned with environment issues, which included " ... harmful consequences of exploitation, and overconsumption". In addition, Bickerstaff and Walker (1999) studied the changes in behaviour and perception among students in response to changes happening in the environment [170]. Initially, they analysed the case with mixed methods, involving 378 students aged from 11 to 16 in three socio-economically diverse residential districts. Interviews were carried out with the students. The study allowed the researchers to gain a broad understanding of the students' views on climate change. The significant findings indicated that the interpretation and evaluation of information can be much more effective when it is related to a student's "local experience". Tedeschi (1982) also expressed a similar belief regarding the relationship between factors such as knowledge of environmental issues, environmental concern, perceptions of personal or environmental control, and selfinterest when he interviewed 106 students at a school [171]. Out of these, 43 students participated in environment issues and concern talks. The other 63 students did not speak as much. The analyst observed that the students who took part felt that environmental issues such as pollution had a direct impact on their lives. The researcher related that the "heightening awareness of the direct effects of environmental issues on students' lives may be more effective" and may encourage pro-environmental behaviour. Pursley utilised a 142-question questionnaire entitled "Young People and the Environment" (Pursley, 2002) with 848 students who were aged between 14 and 16 [172]. The researcher hypothesised that students who reported more pro-environmental attitudes and higher environmental knowledge would demonstrate greater levels of pro-environmental behaviours. This research was supported by previous studies by Kuitunen, Lyons, and Breakwell (1994) and Tikka and Tynys (2000). He found that a higher level of environmental knowledge can influence pro-environmental activities in students [173].

\subsubsection{Empathy and Environmental Behaviours}

Environmental behaviours include terms such as empathy and emotional sensitivity. When these studies relate to the environment, empathy is shown as a cultivator of a student's concern for environmental issues. Some research has also reportedly shown that empathy as well as emotion are excellent methods for the better development of ecological thinking and practice. Berenguer (2007) used an experimental process on 60 students aged from 11 to 13 to show the prediction of "increased helping behaviour toward nature and to feel empathy for a natural object (plant or animal)". Empathic emotions were treated by analysing the response questionnaire filled out by each student. The main results indicate that more positive behaviour and attitudes toward nature were created by the effect of 
empathy on attitudes towards natural objects. These results lay the theoretical groundwork for continued research on empathetic feelings as a factor mediating environmental attitudes and behaviours. However, Iwata (2004) also examined the environmental behaviour and the empathy preferences among 150 students. This report shows a similar positive relationship between empathy and environmental awareness to that of Iwata (1992). The researcher reportedly suggested that empathy is considered to be an important factor in environmental behaviour; however, strong empathy would lead to a decrease in the event of ecological crisis (Iwata, 2004). Ricardo Ernesto et al. (2020) also indicated that certain psychological characteristics are present in some people who exhibit an intimate bond with nature, and also encourage people to participate in environmental care [174].

\section{Conclusions}

This review focused on eco-art education research to show the advances made in the field of environmental education over the past few years. It also offers students the opportunity to gain the knowledge, values, and skills required to protect the environment and learn to appreciate the beauty of the environment. The results of this research demonstrate the areas which need more attention from researchers and educators in the field of environmental education. It also explains the significance of learning about environmental problems in school. Some recommendations have been obtained from the reviewed papers regarding sustainability:

- Schools should offer opportunities to create a well-planned curriculum to highlight environmental issues;

- Leaders must develop educational proposals to motivate students to participate in creating a culture of sustainability. Schools must motivate students to maintain sustainable lifestyles. Here, in Mauritius, the government is motivating students to experience nature and has created some strategies to enhance young Mauritians' environmental awareness [175-177];

- Educators should focus on place-based education to enhancing ecological systems;

- Eco-art education represents new paths, as this review demonstrated;

- We must encourage the participation of students in eco-art education curricula by determining the long-term effects of environmental goals;

- We need research aimed at identifying the role of teachers and students in an eco-art education curriculum.

The findings of the chosen studies reveal that eco-art education has an effect on students in a variety of areas, including their awareness, behaviour, attitude, and actions. To observe the exact effects of eco-art education, further studies should be planned, such as pre-tests and post-tests with a control. Across all outdoor settings, the classroom environment should be used as a control group. This will demonstrate the advantages of using place-based education as a good pedagogy for improving awareness, abilities, effects, behaviour, etc. It may be difficult to comprehend the interdisciplinary essence of environmental education (Palmer, 1998) in a classroom setting, but it will be much easier to grasp this concept outside the classroom. The selected studies have shown a positive result, especially in terms of environmental education dimensions. Students' environmental behaviours and attitudes have been recognised by researchers. Furthermore, some researchers believe that environmental education should not be restricted to formal education class time, because environmental education is a lifelong process. To summarise, the majority of previous research has concentrated on educational methods and tactics to boost students' environmental knowledge and behaviour. However, few studies have looked into the pedagogies that are needed for the effective implementation of environmental education. Environmental education can help to create synergistic research implementation spaces that encourage participation, collaboration, and coproduction among diverse stakeholders $[177,178]$.

Funding: This research received no external funding. 
Institutional Review Board Statement: Not applicable.

Informed Consent Statement: Not applicable.

Data Availability Statement: Not applicable.

Conflicts of Interest: The authors declare no conflict of interest.

\section{References}

1. National Academy of Sciences. Climate change: Evidence ad Causes; The National Academies Press: Washinton, DC, USA, 2020. [CrossRef]

2. Worldwatch Institute. State of the World: Can a City Be Sustainable; Worldwatch Institute and Island Press: Washington, DC, USA, 2016; p. 414.

3. Orr, D.W. Ecological Literacy: Education and the Transition to a Postmodern World. SUNY Series in Constructive Postmodern Thought; State University of New York Press: Albany, NY, USA, 1992.

4. Miller, C. Resisting empire: Globalism, relocation, relocalization, and the politics of knowledge. In Earthly Politics: Local and Global Environmental Governance; Sheila, J., Marybeth, L.M., Eds.; MIT Press: Cambridge, MA, USA, 2004.

5. Moser, S.C. Communication strategies to mobilize the climate movement. In Ignition: What You Can Do to Fight Global Warming and Spark a Movement; Isham, J., Waage, S., Eds.; Island Press: Washington, DC, USA, 2007; pp. 73-93.

6. Maura, A.E.; Pilotti; Runna, A.G. Sustainable education starts in the classroom. Sustainability 2020, $12,9573$.

7. Manoli, C.C.; Johnson, B.; Dunlap, R.E. Assessing children's environmental worldviews: Modifying and validating the new ecological paradigm scale for use with children. J. Environ. Educ. 2007, 38, 3-13. [CrossRef]

8. Orr, D.W. The coming biophilia revolution. Earth Isl. J. 1994, 9, 38-40.

9. Graham, M.A. Art, ecology and art education: Locating art education in a critical placebased pedagogy. Stud. Art Educ. 2007, 48, 375-391. [CrossRef]

10. Hansen, E. Island ecology: An exploration of place in the elementary art curriculum. Art Educ. 2009, 62, 46-51, Retrieved from Education Full Text database. [CrossRef]

11. Greenmuseum.org. What Is Environmental Art? 2010. Available online: http://www.greenmuseum.org/what_is_ea.php (accessed on 23 November 2020).

12. Wallen, R.; Ecological Art: A call for visionary intervention in a time of crisis. Leonardo 2014, 45, 234-242. Available online: http:/ / ruthwallen.net/WallenLeonardo4503 (accessed on 23 November 2020).

13. Cheng, J.C.; Monroe, M.C. Connection to nature: Children's affective attitude toward the environment. Environ. Behav. 2012, 44, 31-49. [CrossRef]

14. Anderson, T.; Guyas, A.S. Earth education, interbeing, and deep ecology. Stud. Art Educ. 2012, 53, 223-245. [CrossRef]

15. Inwood, H. Mapping eco-art education. Can. Rev. Art Educ. Res. Issues 2008, 35, 57-72.

16. Hungerford, H. Environmental education (EE) for the 21st century: Where have we been? Where are we now? Where are we headed? J. Environ. Educ. 2010, 41, 1-6. [CrossRef]

17. Simon, L.; Adam, L.; Michael, T.; Donald, R. Sustainability Education and Environmental Worldviews: Shifting a Paradigm. Sustainability 2020, 12, 8258. [CrossRef]

18. Larijani, M. Assessment of environmental awareness among higher primary school teachers. J. Hum. Ecol. 2010, 31, 121-124. [CrossRef]

19. Hungerford, H.; Peyton, R.; Wilke, T. Goals of curriculum development in Environmental Education. J. Environ. Educ. 1980, 21, 8-21. [CrossRef]

20. Chawla, L. The ecology of environmental awareness and action. In Critical International Perspectives on Participation in Environmental and Health Education; Jensen, B.B., Reid, A., Eds.; Danish University Press: Copenhagen, Denmark, 2009.

21. Stapp, W.B.; Bennett, D.; Bryan, W., Jr.; Fulton, J.; MacGregor, J.; Nowak, P.; Swan, J.; Wall, R.; Havlick, S. The concept of environmental education. J. Environ. Educ. 1969, 1, 30-31. [CrossRef]

22. Disinger, J. Environmental Education's Definitional Problem. (ERIC Information Bulletin, No. 2.); ERIC/SMEAC: Columbus, OH, USA, 1985.

23. Lorbiecke, M. Aldo Leopold: A Fierce Green Fire; Falcon Publishing: Helena, MT, USA, 1996.

24. Hammerman, E. A Delphi formulation of Environmental Education objectives (Doctoral dissertation, Northern Illinois University, DeKalb, IL, 1979). Diss. Abstr. Int. 1980, 40, 2447.

25. Aydemir, M. The Investigation of Teachers with Respect to Knowledge Level on Environmental Concepts. Unpublished. Master Thesis, Middle East Technical University, Ankara, Turkey, 2007.

26. Hungerford, H.R.; Volk, T.L. Changing learner behaviour through environmental education. J. Environ. Educ. 1990, $21,8-21$. [CrossRef]

27. Vreken, N.J.; Rens, J.A. An introduction to Environmental Education; Keurkopie: Potchefstroom, South Africa, 1997.

28. Mistral, R.P. Indian Worldview and Environmental Crisis. Environmental Education for Sustainable Development. Ph.D. Thesis, State University of New York, Albany, NY, USA, 1994.

29. SACOL. Teacher Education: Routes to Competency, Human and Social Sciences in the Classroom. In An Introduction to the Teaching of Human and Social Sciences in South African Schools; Francolin Publishers: Cape Town, South Africa, 1999. 
30. Wilke, J.R. Environmental Education. In Teachers Resource Handbook; A practical guide for K12 Environmental Education Corwin Press: San Jose, CA, USA, 1997.

31. Le Roux, K. Environmental Education Process: Active Learning in Schools; University of Natal: Pietermaritzburg, South Africa, 2001.

32. Hellden, G. Environmental Education and pupils' conception of matter. Environ. Educ. Res. 1995, 1, 267-275. [CrossRef]

33. Stanisstreet, M.; Boyes, E. High school students' perceptions of how major global environmental issues might cause skin cancer. J. Environ. Educ. 1998, 29, 31-36.

34. Guo, D.; Wang, A.; Zhang, A.T. Pollution exposure and willingness to pay for clean air in urban China. J. Environ. Manag. 2010, 261, 110174. [CrossRef] [PubMed]

35. Gambro, J.S.; Switzky, H.N. A national survey of high school students' environmental knowledge. J. Environ. Educ. 1996, 27, 28-34. [CrossRef]

36. Kansu, Y.; Tüysüz, C. Creating an environmental awareness to high school students about waste batteries. J. Nat. Appl. Sci. 2009, $13,123-127$.

37. Kose, S.; Savran-Gencer, A.; Gezer, K.; Erol, G.H.; Bilen, K. Investigation of undergraduate students' environmental attitudes. Int. Electron. J. Environ. Educ. 2011, 1, 85-96.

38. Dunlap, R.E. The new environmental paradigm scale: From marginality to worldwide use. J. Environ. Educ. 2008, 40, 3-18. [CrossRef]

39. Kasapoğlu, A.; Turan, F. Attitude-behaviour relationship in environmental education: A case study from Turkey. Int. J. Environ. Stud. 2008, 65, 219-231. [CrossRef]

40. Stone, M.K.; Barlow, Z. (Eds.) Ecological Literacy: Education Our Children for a Sustainable World; Sierra Club Books and University of California Press: San Francisco, CA, USA, 2005.

41. Sobel, D. Beyond Ecophobia: Reclaiming the Heart of Nature Education; The Orion Society: Great Barrington, MA, USA, 1996.

42. Macarena, E.I.; Isabel, V.L.; Luis, V.A.M.; Francisco, M.C. Environmental Education, an Essential Instrument to Implement the Sustainable Development Goals in the University Context. Sustainability 2020, 12, 7883. [CrossRef]

43. Thomas, G.O.; Poortinga, W.; Sautkina, E. Habit discontinuity, self-activation, and the diminishing influence of context change: Evidence from the UK Understanding Society Survey. PLoS ONE 2018, 11, e0153490. [CrossRef] [PubMed]

44. Clayton, M. Conservation Psychology: Understanding and Promoting Human Care for Nature. Landsc. Ecol 2011, 26, 297-299. [CrossRef]

45. Volk, T.; McBeth, W. Environmental literacy in the United States; North American Association for Environmental Education: Washington, DC, USA, 1998.

46. Stevenson, R.B. A critical pedagogy of place and the critical place(s) of pedagogy. Environ. Educ. Res. 2008, 14, 353-360. [CrossRef]

47. Ardoin. Toward an eco-justice pedagogy. Educ. Stud. 2018, 32, 401-416.

48. Chiarotto, L. Natural curiosity: A resource for teachers: Building children's understanding of the world through environmental inquiry. In The Laboratory School at the Dr. Eric Jackman Institute of Child Study; Ontario Institute for Studies in Education, University of Toronto: Toronto, ON, Canada, 2011.

49. Paterson, J. Integrating Environmental Education. Educ. Digest 2010, 75, 38.

50. Volk, T.L.; Cheak, M.J. The effects of an environmental education program on students, parents, and community. J. Environ. Educ. 2003, 34, 12-25. [CrossRef]

51. Dyment, J.E.; Reid, A. Gaining Ground: The Power and Potential of School Ground Greening in the Toronto District School Board. 2005. Available online: http://ww.evergreen.ca/en/lg/lgresources.html (accessed on 23 November 2020).

52. Larson, L.R.; Green, G.T.; Castleberry, S.B. Effects of an Environmental Education Program on the Environmental Orientations of Children from Different Gender, Age, and Ethnic Groups. J. Park Recreat. Adm. 2010, 28, 95-113.

53. Fiske, E.B. Champions of Change: The Impact of the Arts on Learning, the Arts Education Partnership and the Presidents' Committee on the Arts and the Humanities; Scientific Research: Washington, DC, USA, 1999.

54. Knight, L. Why a Child Needs a Critical Eye, and Why the Art Classroom is Central in Developing it. J. Art Des. Educ. 2010, 29, 236-243. [CrossRef]

55. Krug, D.; Cohen-Evron, N. Curriculum integration positions and practices in art education. Stud. Art Educ. 2000, 41, 259-275. [CrossRef]

56. Blandy, D.; Hoffman, E. Toward an art education of place. Stud. Art Educ. 1993, 35, 22-33. [CrossRef]

57. Ontario Arts Council. Making the Case for Arts Education. 1997. Available online: http://www.arts.on.ca/asset6345.aspx (accessed on 23 November 2020).

58. People for Education. The Arts in Ontario schools. 2012. Available online: http://www.peopleforeducation.ca/wp-content/ uploads/2011/12/People-for-Educationreport-on-the-arts-in-schools-April-2013.pdf (accessed on 23 November 2020).

59. Taieb, A.H.; Hammami, M.; Msahli, S.; Sakli, F. Sensitising children to ecological issues through textile eco-design. Int. J. Art Des. Educ. 2010, 29, 313-320. [CrossRef]

60. Fisk, L.; Wood, E. Best Practices: Ecoschools.ca; TDSB Printing Services: Toronto, OH, USA, 2015.

61. Song, Y. Art in nature and schools: Nils-Udo. J. Aesthetic Educ. 2012, 44, 96-108. [CrossRef]

62. Branagan, M. Environmental Education, activism and the arts. Convergence 2005, 38, 33-50.

63. Banerjee, S. Land as Home: A Portrait of the Circumpolar Arctic in a Rapidly Changing Planet. Santa Fe, New Mexico. 2007. Available online: http:/ / www.subhankarbanerjee.org/banerjee.html (accessed on 2 December 2020). 
64. Minteer, B.A. The Landscape of Reform: Civic Pragmatism and Environmental Thought in America; MIT Press: Cambridge, MA, USA, 2006; p. 264. ISBN 978-0-262-13461-3.

65. Mantere, M.-H. Coming Back to the Senses: An Artistic Approach to Environmental Education. 2004. Available online: http:/ / www.naturearteducation.org/Articles/Coming\%20Back\%20to\%20the\%20Senses.pdf (accessed on 2 December 2020).

66. Jokela, T. Engaged art in the North: Aims, methods, contexts. In Cool: Applied Visual Arts in the North; Jokela, T., Coutts, G., Huhmarniemi, M., Härkönen, E., Eds.; Publications of the Faculty of Art and Design of the University of Lapland: Rovaniemi, Finland, 2013; pp. 10-21.

67. Gablik, S. The Re-Enchantment of Art; Thames and Hudson: New York, NY, USA, 1991.

68. Collins, T A model incorporating the rationale and purpose for conducting mixed-methods research in special education and beyond. Learn. Disabil. A Contemp. J. 2007, 4, 67-100.

69. Eisner, E.W. The Educational Imagination: On the Design and Evaluation of School Programs; Merrill Prentice Hall: Upper Saddle River, NJ, USA, 1999.

70. Cronin-Jones, L.L. Using drawings to assess student perceptions of schoolyard habitats: A case study of reform-based research in the United States. Can. J. Environ. Educ. 2005, 10, 225-240.

71. Tunstall, S.; Tapsell, S.; House, M. Children's perceptions of river landscape and play: What children's photographs reveal. Landsc. Res. 2004, 29, 181-201. [CrossRef]

72. Lewis, D.; Greene, J. Your Child's Drawings...Their Hidden Meaning; Hutchinson: London, UK, 1983.

73. Bowker, R. Children's perceptions and learning about tropical rainforests: An analysis of their drawings. Environ. Educ. Res. 2007, 13, 75-96. [CrossRef]

74. Gardner, H. Frames of Mind: The Theory of Multiple Intelligences; Basic Books: New York, NY, USA, 1993.

75. Alerby, E. A way of visualizing children's and young people's thoughts about the environment: A study of drawings. Environ. Educ. Res. 2000, 6, 205-222. [CrossRef]

76. Barraza, L. Children's drawings about the environment. Environ. Educ. Res. 1999, 5, 49-66. [CrossRef]

77. Smith, M.H.; Meehan, C.L.; Castori, P. Children's drawings: An alternative assessment strategy. In Proceedings of the North American Association for Environmental Educators' 2003 Annual Conference, Anchorage, AK, USA, 17 June 2003.

78. Hoot, J.L.; Foster, M.L. Promoting ecological responsibility through the arts. Child. Educ. 1993, 69, 150-155. [CrossRef]

79. Wilson, S. The Magical Universe; Hambledon \& London: London, UK, 2003.

80. Gradle, S. Ecology of place: Art education in a relational world. Stud. Art Educ. 2007, 48, 392-411. [CrossRef]

81. Blandy, D.; Fenn, J. Sustainability: Sustaining cities and community cultural development. Stud. Art Educ. 2012, 53, 270-282. [CrossRef]

82. Matilsky, B. C Fragile Ecologies: Contemporary Artist' Interpretations and Solutions; Rizzoli: New York, NY, USA, 1992.

83. Gude, O. New School Art Styles by Gude. Art Education, the Journal of the National Education Association. 2013. Available online: https://naea.digication.com/omg/New_School_Art_Styles_the_Project_of_Art_Education (accessed on 2 December 2020).

84. Garoian, C.R. Art education and the aesthetics of land use in the age of ecology. Stud. Art Educ. 1998, 39, 244-261. [CrossRef]

85. Simon, S. Systemic educational approaches to environmental issues: The contribution of ecological art. Syst. Pract. Action Res. 2006, 19, 143-157. [CrossRef]

86. Russell, R.L. Hutzel A beginner's guide to public art. Art Educ. 2004, 57, 19-24. [CrossRef]

87. Upitis, R. Developing ecological habits of mind through the arts. Int. J. Educ. Arts 2009, 10, 1-35.

88. Rosenthal, A. Case studies: Toolbox for Educators. 2004. Available online: http://greenmuseum.org/generic_content.php?ct_id= 171 (accessed on 2 December 2020).

89. Inwood, H. Shades of green: Growing environmentalism through art education. Art Educ. 2010, 63, 33-38. [CrossRef]

90. Lankford, E.L. Ecological stewardship in art education. Art Educ. 1997, 50, 47-53. [CrossRef]

91. Holmes, S. Creative by nature: Integrating the arts into environmental science education. Green Teach. 2002, 69, 23-28.

92. Song, Y.I.K. Crossroads of public art, nature and environmental education. Environ. Educ. Res. 2012, 18, 797-813. [CrossRef]

93. Rosenthal, J.K. Stories of Transformation: Place-Based Education and the Developing Place-Consciousness of Educators along the Hudson River. Doctoral Dissertation, State University of New York, Albany, NY, USA, 2011.

94. Gruenewald, D.A. The best of both worlds: A critical pedagogy of place. Environ. Educ. Res. 2008, 14, 308-324. [CrossRef]

95. Knapp, C.E. The "I-thou" relationship, place-based education, and Aldo Leopold. J. Exp. Educ. 2005, 27, 277-285. [CrossRef]

96. Wakeman, H. Power in Place-Based Education: Why a Critical Pedagogy of Place Needs to Be Revived and How Narratives or Collective Biographies Support Its Practice. Ph.D. Thesis, University of Wyoming, Laramie, WY, USA, 2015.

97. Dillon, J.; Dickie, I. Learning in the Natural Environment: Review of Social and Economic Benefits and Barriers; Natural England Commissioned Reports, Number 092; Natural England: York, UK, 2012.

98. Fjørtoft, I. Motor Fitness in Pre-Primary School Children. Motor Fitness Test explored on 57 Years Old Children. Pediatric Exerc. Sci. 2001, 12, 424-436. [CrossRef]

99. Allison, P. Analysing attempts to support outdoor learning in Scottish schools. J. Curric. Stud. 2013, 45, 418-440.

100. Ernst, J.; Monroe, M. The effects of environment-based education on students' critical thinking skills and disposition toward critical thinking. Environ. Educ. Res. 2006, 12, 429-443. [CrossRef]

101. Quay, J. More than relations between self, others and nature: Outdoor education and aesthetic experience. J. Adventure Educ. Outdoor Learn. 2013, 13, 142-157. [CrossRef] 
102. Beames, S.; Ross, H. Journeys outside the classroom. J. Adventure Educ. Outdoor Learn. 2010, 10, 95-109. [CrossRef]

103. Fägerstam, E. High school teachers' experience of the educational potential of outdoor teaching and learning. J. Adventure Educ. Outdoor Learn. 2014, 14, 56-81. [CrossRef]

104. Waite, S. Teaching and learning outside the classroom: Personal values, alternative pedagogies and standards. Education 2013, 39, 3-13. [CrossRef]

105. Michael, P. Helping Children Fall in Love with the Earth: Environmental Education and the Arts. In Ecological Literacy; Stone, M.K., Barlow, Z., Eds.; Sierra Club Books: San Fransisco, CA, USA, 2005; pp. 111-125.

106. Chiras, D. Ecokids: Raising Children Who Care for the Earth; New Society Publishers: Gabriola, BC, USA, 2005.

107. Rodenburg, J. Pathway to stewardship: A framework for children and youth. In EarthEd: Rethinking Education on a Changing Planet; Assadourian, E., Mastney, L., Eds.; Worldwatch Institute: Washington, DC, USA, 2017; pp. 61-71.

108. Sobel, D. A place in the world: Adults' memories of childhood's special places. Child. Environ. Q. 1991, 7, 5-12.

109. Somerville, M.J. A place pedagogy for 'global contemporaneity'. Educ. Philos. Theory 2010, 42, 326-344. [CrossRef]

110. Chawla, L. Significant life experiences revisited: A review of research. J. Environ. Educ. 1998, 29, 11-22. [CrossRef]

111. Huby, M.; Bradshaw, J. A review of the Environmental Dimension of Children and Young People's Wellbeing: Report Prepared for the Sustainable Development Commission; University of York: York, UK, 2006.

112. Cameron, J.I. Educating for Place Responsiveness: An Australian Perspective on Ethical Practice. Ethics Place Environ. 2003, 6, 99-115. [CrossRef]

113. Solnit, R. As Eve Said to the Serpent: On Landscape, Gender and Art; University of Georgia: Athens, GA, USA, 2001.

114. Taylor, P. Service-learning as postmodern art and pedagogy. Stud. Art Educ. 2002, 43, 124-140. [CrossRef]

115. Anderson, H. A river runs through it: Art education and a river environment. Art Educ. 2000, 53, 13-18. [CrossRef]

116. Congdon, K.G. What I have learned from "Other" art educators. Stud. Art Educ. 2005, 46, 138-149. [CrossRef]

117. Bogner, F.X.; Wiseman, M. Towards Measuring Adolescent Environmental Perception. Eur. Psychol. 1999, 4, 139-151. [CrossRef]

118. Powers, A.L. An evaluation of four place-based education programs. J. Environ. Educ. 2004, 35, 17-32. [CrossRef]

119. Buxton, C.A. Social problem solving through science: An approach to critical, placebased, science teaching and learning. Equity Excell. Educ. 2010, 43, 120-135. [CrossRef]

120. Glaser, B.G.; Strauss, A. The Discovery Grounded Theory: Strategies for Qualitative Inquiry; Aldin: Chicago, IL, USA, 1967.

121. Conaway, J.D. Mississippi river: A Mixed-Method Examination of the Effects of a Place-Based Curriculum on the Environmental Knowledge and Awareness of Montessori Students; Dergi Park Academics: Istanbul, Turkey, 2006.

122. Howley, A.; Howley, M.; Camper, C.; Perko, H. Place-based education at island community school. J. Environ. Educ. 2011, 42, 216-236. [CrossRef]

123. Cook, L.W. Developing a Sense of Place: Examining Educator Practice in Place-Based Education; Dergi Park Academics: Istanbul, Turkey, 2009.

124. Triggs, V. EarthShapes: Potential for place-based teacher learning between the virtual and the actual. Can. J. Environ. Educ. 2009, $14,74-91$.

125. Creel, M.S. The Endangered Species Sculpture Garden: An Interdisciplinary Environmental Art Education Curriculum for At-Risk Children; Dergi Park Academics: Istanbul, Turkey, 2005.

126. Santrock, J.W. Child Development, 9th ed.; McGraw Hill: New York, NY, USA, 2001.

127. Zaki, J. Moving beyond stereotypes of empathy. Trends Cogn. Sci. 2017, 21, 59-60. [CrossRef]

128. De Vignemont, F.; Singer, T. The empathic brain: How, when and why? Trends Cogn. Sci. 2006, 10, 435-441. [CrossRef]

129. Coplan, A. Understanding empathy: Its features and effects. In Empathy: Philosophical and Psychological Perspectives; Coplan, A., Goldie, P., Eds.; Oxford University Press: Oxford, UK, 2014.

130. Berenguer, J. The effect of empathy in proenvironmental attitudes and behaviors. Environ. Behav. 2007, 39, 269-283. [CrossRef]

131. Batson, C.D. The Altruism Question: Toward a Social-Psychological Answer; Lawrence Erlbaum: Hillsdale, NJ, USA, 1991.

132. Berenguer, J. The effect of empathy in environmental moral reasoning. Environ. Behav. 2010, 42, 110-134. [CrossRef]

133. Lanzoni, S. Practicing psychology in the art gallery: Vernon Lee's aesthetics of empathy. J. Hist. Behav. Sci. 2009, 45, 330-354. [CrossRef]

134. Franklin, M. The esthetic attitude and empathy: A point of convergence. Am. J. Art Ther. 1990, 29, 42-48.

135. Koss, J. On the limits of empathy. Art Bull. 2006, 88, 139-157. [CrossRef]

136. White, B. Aesthetics Primer; Peter Lang: Washington, DC, USA, 2009.

137. Oremland, J.D. Empathy and its relation to the appreciation of art. In Empathy I; Lichtenburg, J., Bornstein, M., Silver, D., Eds.; Analytic Press: Hillsdale, NJ, USA, 1984; pp. 239-265.

138. Höge, H. A museum experience: Empathy and cognitive restoration. Empir. Stud. Arts 2003, 21, 155-164. [CrossRef]

139. Freedberg, D.; Gallese, V. Motion, emotion and empathy in esthetic experience. Trends Cogn. Sci. 2007, 11, 197-203. [CrossRef] [PubMed]

140. Iwata, O. Attitudinal determinants of environmentally responsible behavior. Soc. Behav. Personal. An Int. J. 2001, $29,183-190$. [CrossRef]

141. Kollmuss, A.; Agyeman, J. Mind the gap: Why do people act environmentally and what are the barriers to pro-environmental behaviour? Environ. Educ. Res. 2002, 8, 239-260. [CrossRef]

142. Holahan, C.J. Environmental Psychology; Random House: New York, NY, USA, 1982. 
143. Schultz, P.W. The structure of environmental concern: Concern for self, other people, and the biosphere. J. Environ. Psychol. 2001, 21,327-339. [CrossRef]

144. Stern, P.C.; Dietz, T. The value basis of environmental concern. J. Soc. Issues 1994, 50, 65-84. [CrossRef]

145. Bell, P.A.; Greene, T.C.; Fisher, J.D.; Baum, A. Environmental Psychology, 5th ed.; Harcourt College Publishers: New York, NY, USA, 2001.

146. Scott, D.; Willits, F.K. Environmental attitudes and behavior: A Pennsylvania survey. Environ. Behav. 1994, 26, 239-260. [CrossRef]

147. Buttel, F.H.; Flinn, W.L. Social class and environmental beliefs: A reconsideration. Environ. Behav. 1978, 10, 433-450. [CrossRef]

148. Grieve, K.W.; Van Staden, F. Environmental concern in South Africa: An attitudinal study. South Afr. J. Psychol. 1985, 15, 135-136. [CrossRef]

149. Reynolds, D. Special Issue: Country reports from Australia, the Netherlands, the UK and the United States of America. School Eff. Improv. 1992, 7, 111-195. [CrossRef]

150. Craffert, L.; Willers, V.A. Public perceptions of environmental issues. Inf. Update 1994, 41-47.

151. Willers, V.; Van Staden, F. Environmental concern and environmentally responsible behaviour: Towards a model. South. Afr. J. Environ. Educ. 1996, 18, 29-37.

152. Knuth, S. Global finance and the land grab: Mapping twenty-first century strategies. Can. J. Dev. Stud. 2001, 36, 163-178. [CrossRef]

153. Fiedeldey, A.C.; Craffert, L.; Fiedeldey-Van Dijk, C.; Marais, J.L.; Van Staden, F.J.; Willers, V. Human Values, Attitudes and Perceptions of the Environment: The South African PAGEC Study; University of Pretoria: Pretoria, South Africa, 1998.

154. Arcury, T.A.; Christianson, E.H. Environmental worldview in response to environmental problems: Kentucky 1984 and 1988 compared. Environ. Behav. 1990, 22, 387-407. [CrossRef]

155. Lyons, E.; Breakwell, G.M. Factors predicting environmental concern and indifference in 13- to 16-year-olds. Environ. Behav. 1994, 26, 223-238. [CrossRef]

156. Blum, A. Student's knowledge and beliefs concerning environmental issues in four countries. J. Environ. Educ. 1987, 18, 7-13. [CrossRef]

157. Williams, S.M.; McCrorie, R. The analysis of ecological attitudes in town and country. J. Environ. Manag. 1989, 31, 157-162. [CrossRef]

158. Lindemann-Matthies, P. Children's Perception of Biodiversity in Everyday Life and Their Preferences for Species. Ph.D. Thesis, University of Zürich, Zürich, Switzerland, 2002.

159. Taylor, D.E. Blacks and the environment: Toward an explanation of the concern and action gap between blacks and whites. Environ. Behav. 1989, 21, 175-205. [CrossRef]

160. Kostka, M.D. Nature center program impact. J. Environ. Educ. 1976, 8, 52-64. [CrossRef]

161. Kuhlemeier, H.; Van den Berg, H.; Lagerweij, N. Environmental knowledge, attitudes, and behavior in Dutch secondary education. J. Environ. Educ. 1999, 30, 4-14. [CrossRef]

162. Vaske, J.J.; Kobrin, K.C. Place attachment and environmentally responsible behavior. J. Environ. Educ. 2001, 32, 16-21. [CrossRef]

163. Mohd, Y.Y.; Amirudin, A.; Raden, A.R.; Nik, A.N.S.A.; Thurasamy, R.; Zikri, M.; Francesca, D.M.; Maurizio, M.; Jumadil, S.; Safiek, M. An Investigation of Pro-Environmental Behaviour and Sustainable Development in Malaysia. Sustainability 2020, 12, 7083. [CrossRef]

164. Kaiser, F.G.; Wolfing, S.; Fuhrer, U. Environmental attitude and ecological behaviour. J. Environ. Psychol. 1999, 19, 1-19. [CrossRef]

165. Fuhrer, U.; Wolfing, S. Von den Sozialen Grundlagen des Umweltbewusstseins zum Verantwortlichen Umwelthandeln: Die Sozialpsychologische Dimension der Umweltproblematik [From the Social Basis of Environmental Concern to Responsible Ecological Action: The Socialpsychological Dimension of Environmental Problems]; Huber: Bern, Switzerland, 1997.

166. Weigel, R.; Weigel, J. Environmental concern: The development of a measure. Environ. Behav. 1978, 10, 3-15. [CrossRef]

167. Dunlap, R.E.; Van Liere, K.D.; Mertig, A.G.; Jones, R.E. Measuring endorsement of the new ecological paradigm: A revised NEP scale. J. Soc. Issues 2000, 56, 425-442. [CrossRef]

168. Sherburn, M.; Devlin, A.S. Academic major, environmental concern, and arboretum use. J. Environ. Educ. 2004, 35, 23-36. [CrossRef]

169. Kaplan, R. Patterns of environmental preference. Environ. Behav. 1977, 9, 195-216. [CrossRef]

170. Bickerstaff, K.; Walker, G. Clearing the smog. Public responses to air-quality information. Local Environ. 1999, 4, 279. [CrossRef]

171. Siegfried, W.D.; Tedeschi, R.G.; Cann, A. The generalizability of attitudinal correlates of proenvironmental behavior. J. Soc. Psychol. 1982, 118, 287-288. [CrossRef]

172. Pursley, J. An Examination of the Relationship between Adolescent Self-Efficacy and Environmental Behaviors, Knowledge, and Attitudes. Unpublished. Master's Thesis, Washington State University, Pullman, WA, USA, 2000.

173. Tikka, P.M.; Kuitunen, M.T.; Tynys, S.M. The effects of educational background on students' attitudes, activity, and knowledge concerning the environment. J. Environ. Educ. 2000, 31, 12-19. [CrossRef]

174. Ricardo, E.P.I.; César, O.T.-F.; Blanca, S.F.-S.; Natalia, N.S.; Lucia, P. Psychosocial Predispositions Towards Sustainability and Their Relationship with Environmental Identity. Sustainability 2020, 12, 7195. [CrossRef]

175. Bokhoree, C.; Artee, J.; Ravhee, B. Environmental Clubs as Vehicles for Promoting Education for Environmental Sustainability in Mauritian Secondary Schools. Int. J. Environ. Cult. Econ. Soc. Sustain. Annu. Rev. 2012, 7, 177-190. [CrossRef]

176. Bokhoree, C.; Baldeo, R.; Desvaux-Thomas, D.; Ramprosand, S. The Role of Education in Understanding Climate Change's Impacts on Water Resources. Int. J. Climate Change Impacts Responses 2012, 3, 149-165. [CrossRef] 
177. Beeharry, Y.; Makoondlall-Chadee, T.; Bokhoree, C. Policy Analysis for Performance Assessment of Integrated Coastal Zone Management Initiatives for Coastal Sustainability. APCBEE Procedia. 2014, 9, 30-35. [CrossRef]

178. Weintraub, L. To life! Eco Art in Pursuit of a Sustainable Planet. [Kindle DX version]. 2012. Available online: Amazon.ca (accessed on 2 December 2020). 